\title{
A role for the catalytic ribonucleoprotein RNase $P$ in RNA polymerase III transcription
}

\author{
Robert Reiner, Yitzhak Ben-Asouli, Ilana Krilovetzky, and Nayef Jarrous ${ }^{1}$ \\ Department of Molecular Biology, The Hebrew University-Hadassah Medical School, Jerusalem 91120, Israel
}

\begin{abstract}
The physical and functional links between transcription and processing machines of tRNA in the cell remain essentially unknown. We show here that whole HeLa extracts depleted of ribonuclease P (RNase P), a tRNA-processing ribonucleoprotein, exhibit a severe deficiency in RNA polymerase (Pol) III transcription of tRNA and other small, noncoding RNA genes. However, transcription can be restored by the addition of a purified holoenzyme. Targeted cleavage of the H1 RNA moiety of RNase P alters enzyme specificity and diminishes Pol III transcription. Moreover, inactivation of RNase P by targeting its protein subunits for destruction using small interfering RNAs inhibits Pol III function and Pol III-directed promoter activity in the cell. RNase P exerts its role in transcription through association with Pol III and chromatin of active tRNA and 5S rRNA genes. The results demonstrate a role for RNase P in Pol III transcription and suggest that transcription and early processing of tRNA may be coordinated.
\end{abstract}

[Keywords: RNase P; RNA polymerase III; small, noncoding RNA gene; catalytic ribonucleoprotein; tRNA processing]

Supplemental material is available at http://www.genesdev.org.

Received November 15, 2005; revised version accepted April 13, 2006.

Transfer of genetic information requires tRNA, which serves as the adaptor between mRNA and protein. This fundamental role of tRNA requires that newly transcribed primary transcripts of tRNA be accurately processed to mature forms (Wolin and Matera 1999; Hopper and Phizicky 2003). However, how transcription and processing machines cooperate to ensure normal biosynthesis of tRNA in the cell remains essentially unknown.

RNA polymerase (Pol) III transcribes tRNA and other small, noncoding RNA genes in human cells. Transcription of tRNA genes by Pol III has been extensively studied in terms of promoter requirement and subunit recruitment (see Geiduschek and Kassavetis 2001; Schramm and Hernandez 2002; Roeder 2003; White 2005). tRNA genes contain type 2 promoters that are recognized by the transcription initiation factor TFIIIC that recruits TFIIIB, and then both factors assist the joining of Pol III to form a preinitiation transcription complex (Schramm and Hernandez 2002; Roeder 2003). 5S rRNA genes have type 1 promoter while U6 snRNA and 7SL RNA (SRP RNA) genes possess type 3 promoters, which are bound by distinct sets of factors that recruit Pol III (Schramm and Hernandez 2002; Roeder 2003).

${ }^{1}$ Corresponding author.

E-MAIL jarrous@md.huji.ac.il; FAX 972-2-6784010.

Article is online at http://www.genesdev.org/cgi/doi/10.1101/gad.386706.
Newly transcribed precursor transcripts of tRNA undergo processing and modifications through several steps, which include the removal of the $5^{\prime}$ leader sequence, elimination of the 3 ' trailer sequence, splicing of introns in some tRNA isotypes, addition of CCA, and modification of nucleotides (Wolin and Matera 1999; Hopper and Phizicky 2003). Some of these steps of tRNA biogenesis are spatially and temporally ordered (Hopper 1998; Wolin and Matera 1999; Phizicky 2005) and regulated by the La protein (Intine et al. 2002), which has been shown to bind to chromatin of tRNA genes (Fairley et al. 2005).

Removal of the $5^{\prime}$ leader sequence of precursor tRNA is carried out by ribonuclease $\mathrm{P}$ (RNase $\mathrm{P})$, a ubiquitous ribonucleoprotein endonuclease (Altman 2000). Bacterial RNase P has a catalytic RNA moiety that is associated with a single protein cofactor (Guerrier-Takada et al. 1983). Eukaryal RNase P ribonucleoproteins are large particles, when compared with their bacterial counterparts (Jarrous and Altman 2001; Xiao et al. 2002). The catalytically active form of human nuclear RNase P consists of an RNA component, termed H1 RNA, and at least 10 distinct protein subunits, designated Rpp14, Rpp20, Rpp21, Rpp25, Rpp29, Rpp30, Rpp38, Rpp40, hPop1, and hPop5 (see Jarrous and Altman 2001; van Eenennaam et al. 2001). Most of these proteins are shared with the mitochondrial and rRNA-processing ribonucleoprotein RNase MRP /Clayton 2001; van 
Eenennaam et al. 2001). In fact, H1 RNA and its protein subunits are differentially concentrated in distinct intranuclear compartments-e.g., nucleolus, nucleoplasm, and Cajal bodies (Jarrous et al. 1999; van Eenennaam et al. 2001) - in which it is suggested that transcription and processing machines are assembled and modified (Gall 2003). Since these intranuclear compartments are known to be associated with specialized transcriptional activities and their structural integrity is dependent on continuous RNA synthesis (Lamond and Earnshaw 1998; Pombo et al. 1999), we have proposed that the assembly and function of human RNase P are linked to gene transcription (Jarrous 2002).

We show here that human RNase P is required for Pol III transcription of tRNA as well as other small, noncoding RNA genes in whole HeLa extracts and in cells. RNase P acts as a catalytic ribonucleoprotein in Pol III transcription and exerts its role through association with Pol III and chromatin of active tRNA and 5S rRNA genes. Our study reveals a role for a catalytic ribonucleoprotein-i.e., RNase P in Pol III transcription-and suggests that tRNA gene expression may be coordinated at transcription and processing level.

\section{Results}

RNase P activity associates with core and specific subunits of Pol III

Coimmunoprecipitation studies revealed that RNase P activity, identified by processing of the $5^{\prime}$ leader sequence of a ${ }^{32} \mathrm{P}$-labeled precursor tRNA ${ }^{\mathrm{Tyr}}$ (see Materials and Methods), was brought down from HeLa cells by the use of monoclonal antibodies directed against RPB6 (also known as HsRPABC2/RPB14.4) and RPB8 (HsRPABC3/ RPB17) (Fig. 1A, lanes 3-7), two core protein components of Pol I, II and III (Woychik et al. 1990). This coimmunoprecipitation of RNase $P$ activity was sensitive to increasing concentrations of salt (Fig. 1B, cf. lanes 3,5 and 4,6). An affinity-purified monoclonal antibody directed against RPC32 (also known as HsRPC7; Jones et al. 2000), a specific protein component of Pol III that is required for promoter-dependent initiation of transcription (Wang and Roeder 1997) also brought down RNase P activity from HeLa cells (Fig. 1A, lane 8). Similar results were obtained using a monoclonal antibody directed against RPC39 (HsRPC6) (Fig. 1C, lanes 3-5), another specific subunit of Pol III (Wang and Roeder 1997). An antibody directed against Bdp1, a subunit of TFIIIB, also brought down RNase P activity (Fig. 1C, lanes 6,7). The anti-RPC32, anti-RPC39, and anti-Bdp1 antibodies were used at optimal quantities since the use of excess amount of these antibodies in coimmunoprecipitation assays was not more effective in bringing down RNase P activity (Fig. 1D). As positive control for immunoprecipitation (IP) of RNase P, we utilized polyclonal antibodies directed against Rpp21 (Fig. 1B [lanes 7,8], C [lane 8]). Rpp21 is a specific subunit of active RNase P (Fig. 1F, lanes 5,6) and not shared with RNase MRP, as determined by Northern blot analysis of immunoprecipitated
RNAs (Fig. 1E). Thus, antibodies directed against endogenous Rpp21 and myc-tagged Rpp21 expressed in transfected HeLa cells mainly brought down the 340-nucleotide (nt) H1 RNA subunit of human RNase P (Fig. 1E, lanes 4,6,7), while antibodies against other Rpp subunits precipitated the 265-nt RNase MRP RNA as well (Fig. $1 \mathrm{E}$, lanes 3,5).

The results described above show that RNase P activity can be coimmunoprecipitated with protein subunits of human Pol III.

\section{RNase $P$ is required for $t R N A$ gene transcription in vitro}

Transcription of an intron-containing human tRNA ${ }^{\text {Tyr }}$ gene (Fig. 2A; van Tol et al. 1987) was carried out in whole HeLa extracts (Baer et al. 1990) subjected to immunodepletion analysis (see Materials and Methods). In control extracts that were incubated with preimmune serum or Protein A/G agarose beads, transcription of the tRNA $^{\text {Tyr }}$ gene produced a 112-nt primary transcript that was promptly spliced to a stable $92-n t$ tRNA ${ }^{\text {Tyr }}$ intermediate, which was subsequently processed at both termini to produce the mature 76-nt tRNA ${ }^{\mathrm{Tyr}}$ (Fig. 2B, lanes 5-7,11; see van Tol et al. 1987). By contrast, a severe reduction of $\sim 90 \%$ in the synthesis of RNAA $^{\text {Tyr }}$ was measured in extracts immunodepleted with polyclonal antiRpp21 antibodies (Fig. 2B, lane 4), when compared with tRNA $^{\text {Tyr }}$ synthesis in extracts treated with preimmune serum (Fig. 2B, lane 7). A comparable reduction in tRNA $^{\text {Tyr }}$ synthesis was observed in an extract immunodepleted with a monoclonal antibody directed against RPC32 (Fig. 2B, lane 10).

Transcription of the $\mathrm{tRNA}^{\mathrm{Tyr}}$ gene can be restored in the RNase P-depleted extract by adding back its corresponding immunoprecipitate (Fig. 2B, cf. lanes 8 and 4). Western blot analyses detected RPB8 and RPC39 in the immunoprecipitates of anti-Rpp21 antibodies (Fig. 2D, cf. lanes 1-3 and 7), even though the majority of these two subunits remained in the immunodepleted extracts (IDs) (Fig. 2D, lanes 1-6). This latter finding suggests that a small fraction of RNase $\mathrm{P}$ activity in the extract was associated with Pol III. We could not detect RPC32 in the immunoprecipitates of anti-Rpp21 antibodies (Fig. 2D, lanes 1-3, third panel), possibly because this subunit is less abundant than RPC39 (see Wang and Roeder 1997).

Inhibition of transcription in whole HeLa extracts immunodepleted of RNase $\mathrm{P}$ activity is not restricted to the tRNA $^{\text {Tyr }}$ gene. Thus, depletion of RNase P activity from extracts using anti-Rpp21 antibodies resulted in inhibition of the synthesis of human tRNA ${ }_{i}{ }^{\text {Met }}$ (Fig. 2E, cf. lanes 3 and $5 ;$ tRNA $\left._{i}{ }^{\text {Met }}\right)$. This deficiency could be alleviated by adding back the immunoprecipitated material to the depleted extract (Fig. 2E, cf. lanes 6 and 3; ptRNA $\left._{i}{ }^{\text {Met }}\right)$. Nonetheless, the newly transcribed primary transcripts of $\mathrm{tRNA}_{\mathrm{i}}{ }^{\text {Met }}$ were not processed to mature 75-nt tRNA ${ }_{i}^{\text {Met }}$ (Fig. 2E, lane 6). Since this observation was reproduced with precursor transcripts of tRNA ${ }^{\text {Tyr }}$ 

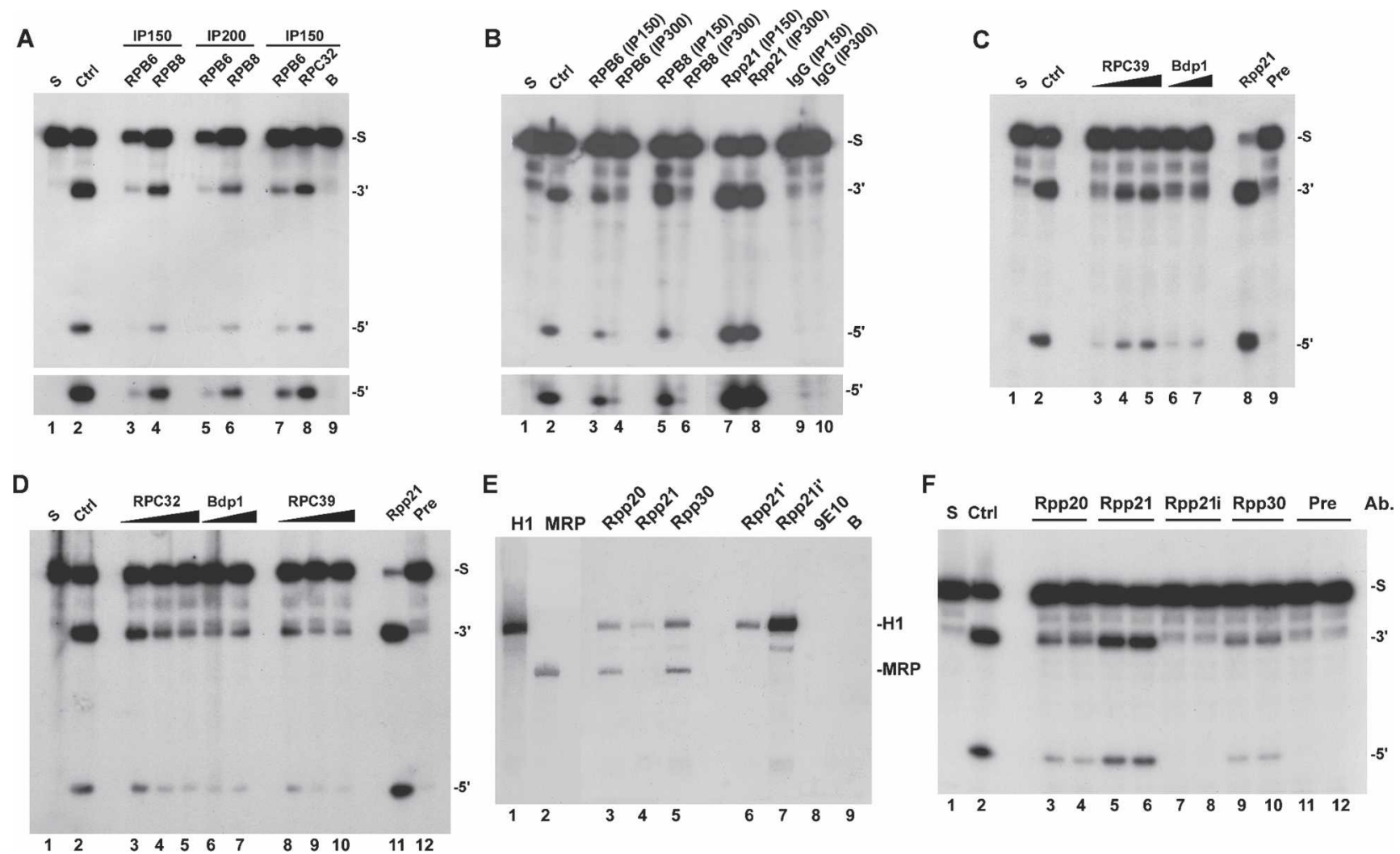

Figure 1. Coimmunoprecipitation of RNase P activity with Pol III subunits. (A) Whole HeLa extracts were subjected to IP analysis using monoclonal anti-RPB6 (lanes 3,5,7), anti-RPB8 (lanes 4,6), or affinity-purified anti-RPC32 (lane 8) antibodies, or beads alone (B; lane 9). IPs were done in the presence of 150 and $200 \mathrm{mM} \mathrm{NaCl}$, and immunoprecipitates obtained were tested for RNase P activity in processing of a ${ }^{32} \mathrm{P}$-labeled E. coli precursor tRNA ${ }^{\mathrm{Tyr}}(\mathrm{S})$. (Lane 2) A purified HeLa RNase P was used as control for substrate cleavage (Ctrl). Cleavage products, tRNA $\left(3^{\prime}\right)$, and $5^{\prime}$ leader sequence $\left(5^{\prime}\right)$ were analyzed in $8 \%$ polyacrylamide/7 M urea gel and bands were visualized by autoradiography. A longer exposure of the $5^{\prime}$ leader sequence is shown in the lower panel. $(B)$ Coimmunoprecipitation of RNase P activity from extracts using monoclonal anti-RPB6 (lanes 3,4) and anti-RPB8 (lanes 5,6) antibodies or polyclonal anti-Rpp21 (lanes 7,8) or anti-human IgG (lanes 9,10) antibodies was done in the presence of 150 and $300 \mathrm{mM} \mathrm{NaCl}$. (C) Coimmunoprecipitation of RNase P activity using 20, 40, and $60 \mu \mathrm{L}$ of monoclonal anti-RPC39 antibodies (lanes 3-5) or 40 and $60 \mu \mathrm{L}(200 \mu \mathrm{g} / \mathrm{mL})$ of polyclonal anti-Bdp1 antibodies (lanes 6,7) coupled to beads. (Lanes 8,9) Polyclonal anti-Rpp21 antibodies and preimmune serum were used as positive and negative controls. $(D)$ Coimmunoprecipitation of RNase P activity using 60, 80, and $120 \mu \mathrm{L}$ of monoclonal anti-RPC32 antibodies (lanes 3-5); 60 and $120 \mu \mathrm{L}(200 \mu \mathrm{g} / \mathrm{mL})$ of polyclonal anti-Bdp1 antibodies (lanes 6,7); or 60, 80, and 120 $\mu \mathrm{L}$ of anti-RPC39 antibodies (lanes 8-10). (Lanes 11,12) Polyclonal anti-Rpp21 antibodies or preimmune serum were used as controls. $(E)$ Northern blot analysis of RNA extracted from immunoprecipitates obtained by the use of antibodies directed against Rpp20, Rpp21, Rpp30, or myc-tagged Rpp21, and myc-tagged Rpp21i, a splice variant expressed in transfected HeLa cells (lanes 3-7) using antisense ${ }^{32} \mathrm{P}-1 \mathrm{labeled}$ H1 RNA and MRP RNA as probes. (Lanes 8,9) A monoclonal anti-myc antibody, 9E10, and beads alone were used as controls. (Lanes 1,2) In vitro transcribed, sense H1 RNA and MRP RNA were tested as internal controls (shorter exposure is attached). Positions of the 340-nt H1 RNA and 265-nt MRP RNA are indicated. (F, lanes 3-10) IP of RNase P activity by antibodies against Rpp20, Rpp21, Rpp21i, and Rpp30 was performed as described in $A$.

(Fig. 2B, lane 8) the immunodepletion procedure of RNase $P$ caused defect in the $5^{\prime}$ tRNA processing capability of the reconstituted extract.

Depletion of whole HeLa extracts from RNase P activity by the use of polyclonal antibodies directed against Rpp40, another protein subunit of human RNase P (Jarrous and Altman 2001), caused a marked decline of $~ 90 \%$ in transcription of the tRNA ${ }^{\mathrm{Tyr}}$ gene (Fig. 2F, lanes 3,4) when compared with transcription in control extracts (Fig. 2F, lanes 7,8). As expected, extracts treated with monoclonal antibodies directed against RPC32 and RPC39 showed severe reductions in transcription of the tRNA $^{\text {Tyr }}$ gene (Fig. 2F, lanes 5,6, respectively).
Our coimmunoprecipitation analyses reveal that the association of RNase P activity with Pol III components was sensitive to increasing concentrations of salt (Fig. 1B). This observation was exploited to show that depletion of RNase P and not its associated Pol III components is responsible for inhibition of tRNA gene transcription in whole HeLa extracts. Thus, we performed immunodepletion of RNase P activity from whole HeLa extracts in the presence of $0.1,0.2$, and $0.3 \mathrm{M} \mathrm{KCl}$ (Fig. 3B, lanes 3-5), and the resultant immunodepleted extracts were dialyzed and tested for tRNA $_{i}{ }^{\text {Met }}$ gene transcription (Fig. 3A). The dialysis step was included to eliminate the inhibitory effect of 
A

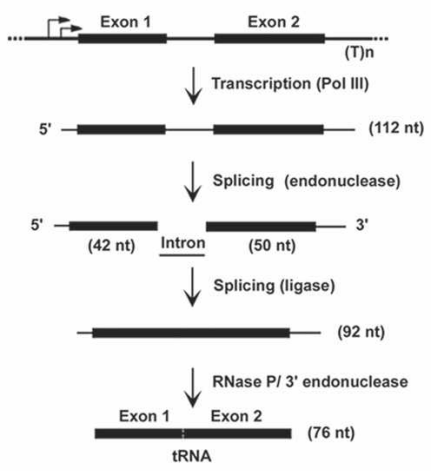

D

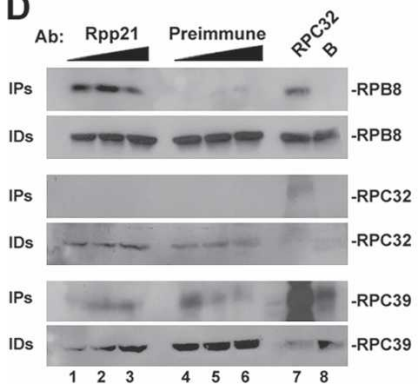

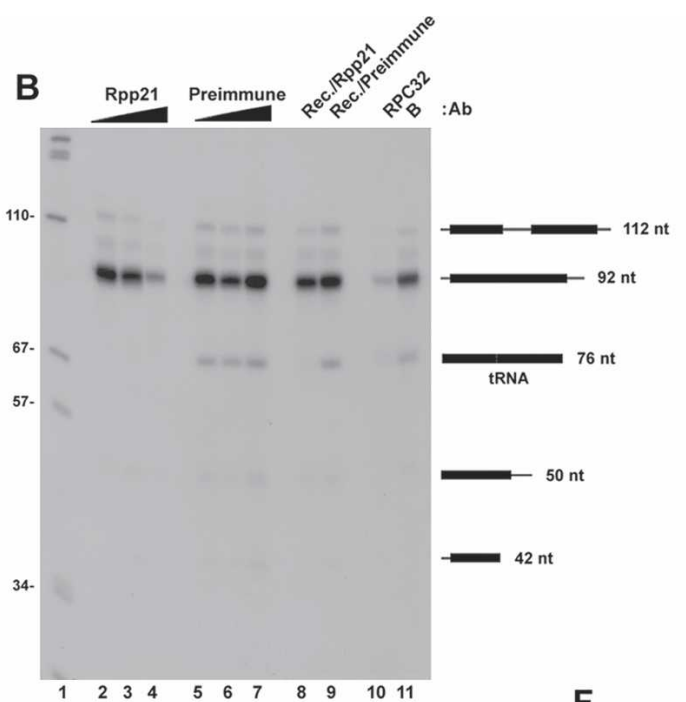
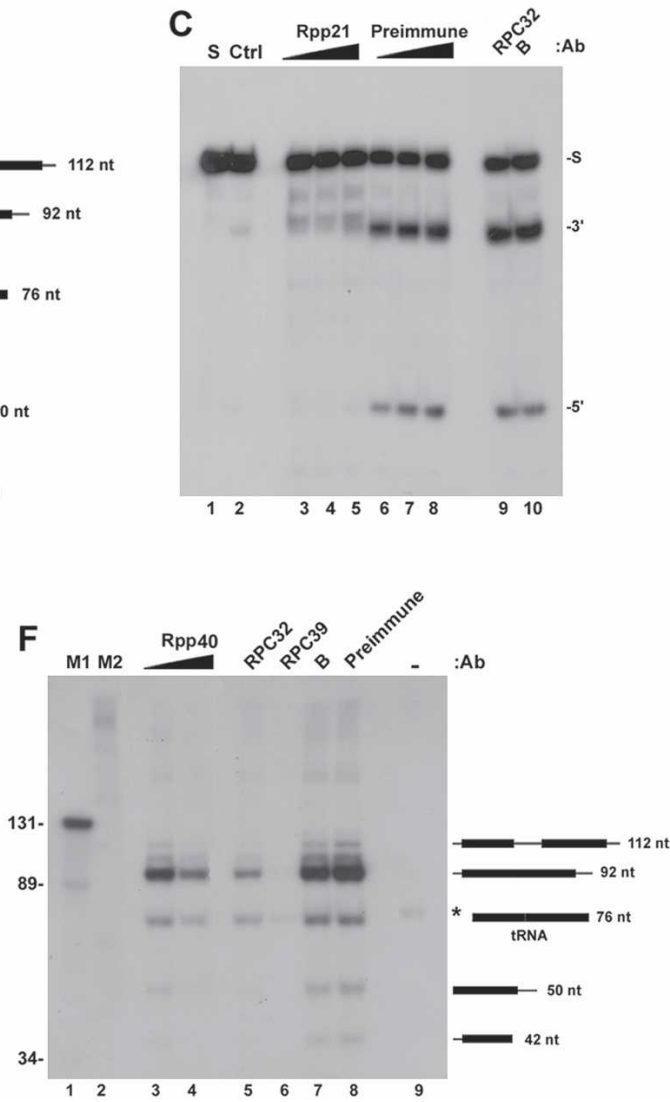

Figure 2. Whole HeLa extracts immunodepleted of RNase P activity are deficient in transcription of tRNA genes. (A) A scheme of a human tRNA ${ }^{\text {Tyr }}$ gene and processing pathway of its precursor tRNA transcript (see van Tol et al. 1987). A human tRNA ${ }^{\text {Tyr }}$ gene has two transcription initiation sites (arrows), but the productive primary transcript (112 nt) is shown. The primary transcript has two exons separated by an intron $(20 \mathrm{nt})$ that is promptly excised to release the exons with $5^{\prime}$ leader and $3^{\prime}$ trailer sequences (42 and $50 \mathrm{nt}$ in length, respectively). These two exons with flanking sequences are then ligated to produce a 92-nt intermediate precursor tRNA ${ }^{\text {Tyr }}$. This intermediate is processed by RNase $\mathrm{P}$ that removes the $5^{\prime}$ leader sequence $(5 \mathrm{nt})$ and by a $3^{\prime}$ endonuclease that eliminates the $3^{\prime}$ trailer sequence (11 nt) to generate mature 76-nt tRNA ${ }^{\text {Tyr }}$. (B) Whole HeLa extracts (Baer et al. 1990) were subjected to immunodepletion analysis using 75, 150, and $225 \mu \mathrm{L}$ of serum containing polyclonal anti-Rpp21 antibodies (lanes 2-4), preimmune serum (lanes $5-7), 30 \mu \mathrm{L}$ of monoclonal anti-RPC32 antibody (lane 10), or agarose beads (B; lane 11). Transcription reactions in the immunodepleted extracts were carried out using a human tRNA ${ }^{\text {Tyr }}$ gene, and labeled RNAs were analyzed in an $8 \%$ sequencing gel. Positions of the 112-nt primary transcript, the 92-nt intermediate tRNA, mature tRNA, and free exons with flanking sequences are indicated. In lanes 8 and 9, immunoprecipitates were added back to their corresponding immunodepleted extracts described in lanes 4 and 7, respectively. (Lane 1) A DNA size marker is shown. (C, lane 1) Extracts described in $B$ were tested for RNase P activity in processing of precursor tRNA $^{\text {Tyr }}(\mathrm{S})$. (Lane 2) Substrate cleavage by a DEAE-purified HeLa RNase P is shown (Ctrl). (D) Immunodepleted extracts (IDs) and their corresponding immunoprecipitates (IPs) described in $B$ were examined for the presence of RPB8 (17.1 kDa), RPC32 (25.9 kDa), and RPC39 (35.6 kDa) by Western blot analysis. $(E)$ Whole HeLa extracts were subjected to immunodepletion analysis as described in $B$. Transcription reactions using a human $\mathrm{tRNA}_{\mathrm{i}}{ }^{\text {Met }}$ gene were performed as in $B$. Positions of the 89-nt precursor tRNA ${ }_{\mathrm{i}}^{\text {Met }}$ and 75 -nt tRNA $_{i}{ }^{\text {Met }}$ are indicated. In lanes 6 and 7, immunoprecipitates were added back to their corresponding immunodepleted extracts described in lanes 3 and 5, respectively. (F) Whole HeLa extracts were subjected to immunodepletion analysis using 50 and $120 \mu \mathrm{L}$ of polyclonal anti-Rpp40 antibodies (lanes 3,4), anti-RPC32 antibody (lane 5), anti-RPC39 antibody (lane 6), agarose beads (lane 7), or preimmune serum (lane 8). Transcription of the tRNA ${ }^{\mathrm{Tyr}}$ gene was performed as in $B$. (Lane 9) A transcription reaction done without template in an untreated extract is shown. Asterisk points to endogenous tRNA ${ }^{\text {His }}$ labeled with ${ }^{32} \mathrm{P}-\mathrm{GTP}$ by a guanylyl transferase activity found in extracts (Domitrovich and Kunkel 2003).

high concentrations of $\mathrm{KCl}$ on Pol III transcription (Fig. 3A, lanes 8,9). We found that when compared with extracts treated with preimmune serum, those immunodepleted of RNase P activity by anti-Rpp29 antibodies (Fig. 3B, lanes 3-5) were all deficient in transcription of the $\mathrm{tRNA}_{\mathrm{i}}{ }^{\mathrm{Met}}$ gene regardless of salt concentration (Fig. 3A, cf. lanes 1-3 and 4-6), though the control extract treated with $0.3 \mathrm{M} \mathrm{KCl}$ exhibited a decrease in Pol III transcription in spite of dialysis (Fig. 3A, cf. lanes 6 and 4,5$)$. 

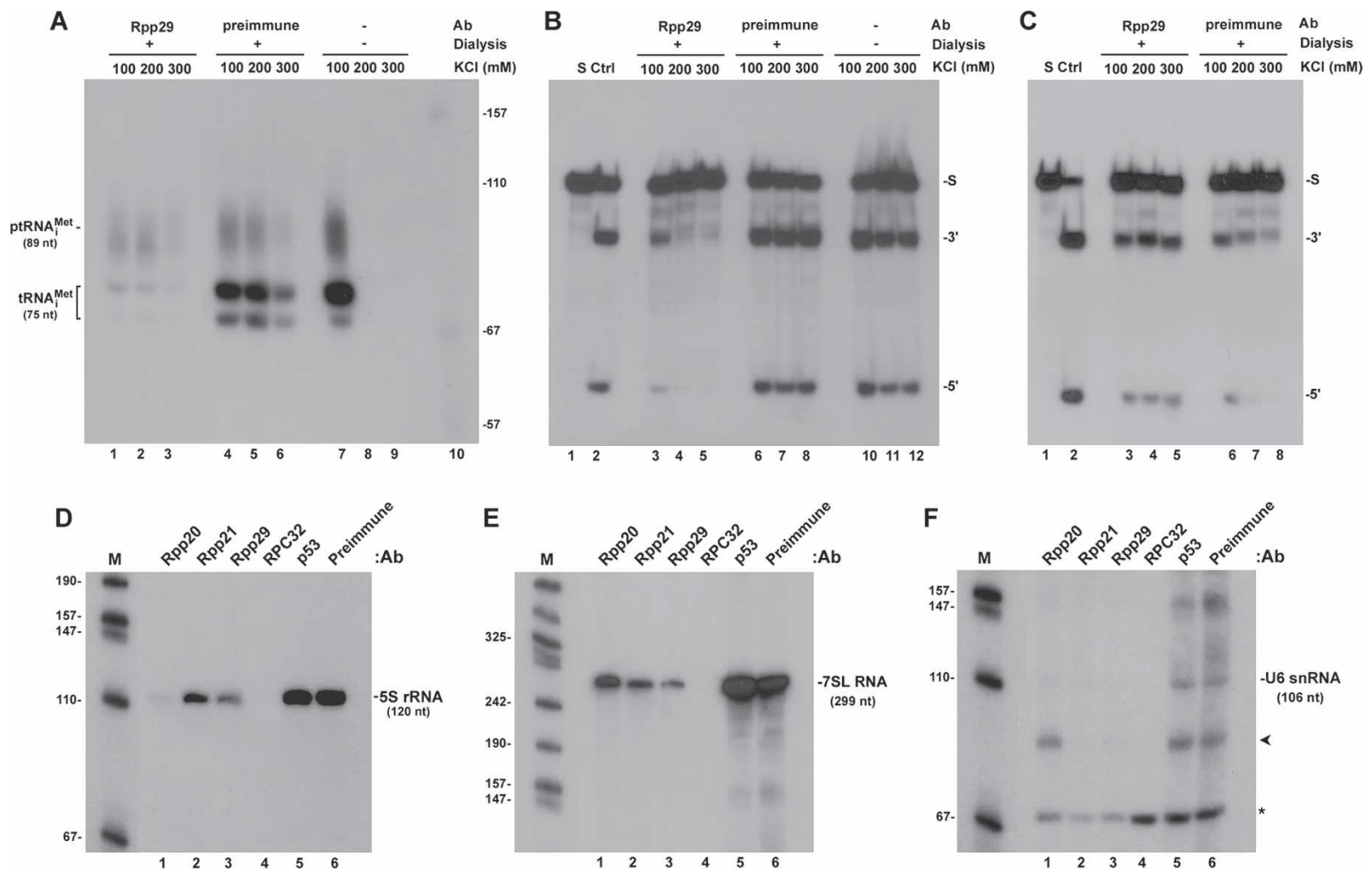

Figure 3. RNase $\mathrm{P}$ is required for in vitro transcription of various small, noncoding RNA genes. $(A)$ Whole HeLa extracts were immunodepleted with polyclonal anti-Rpp29 antibodies (lanes 1-3) or preimmune serum (lanes 4-6) in the presence of 0.1, 0.2 , and 0.3 $\mathrm{M} \mathrm{KCl}$. The resultant immunodepleted extracts were then dialyzed and tested for transcription of the $\operatorname{tRNA}_{i}{ }^{\text {Met }}$ gene as described in Figure 2E. The positions of the 89-nt primary transcript and the 75-nt mature tRNA ${ }_{i}^{\text {Met }}$ are indicated. In lanes 7-9, the inhibitory effect of 0.2 and $0.3 \mathrm{M} \mathrm{KCl}$ on $\mathrm{tRNA}_{\mathrm{i}}{ }^{\text {Met }}$ gene transcription in nondialyzed extracts is shown. $(B)$ Extracts described in $A$ were assayed for RNase $\mathrm{P}$ activity in tRNA processing as described in Figure 2C. $(C)$ The immunoprecipitates obtained in $A$ were assayed for RNase $\mathrm{P}$ activity. (Lane 6) At low salt concentration, preimmune serum precipitates some enzyme activity. (D-F) Whole extracts were prepared from growing HeLa cells, subjected to immunodepletion using antibodies directed against Rpp20 (lane 1), Rpp21 (lane 2), Rpp29 (lane 3), RPC32 (lane 4), p53 (lane 5), or preimmune serum (lane 6), and then the immunodepleted extracts were split and analyzed for transcription of 5S rRNA or 7SL RNA and U6 snRNA (see Materials and Methods). The resultant 120-nt 5S rRNA, 299-nt 7SL RNA, and 106-nt U6 snRNA were all analyzed in the same $8 \%$ sequencing gel. $E$ and $F$ represent the upper and lower parts of the same gel with different exposures. Different exposures of the DNA size marker are attached to each panel. Asterisk points to labeled tRNA ${ }^{\text {His }}$, and arrowhead indicates an aberrant U6 snRNA transcript.

\section{RNase $P$ is required for transcription of various small, noncoding RNA genes by Pol III}

Whole HeLa extracts were subjected to immunodepletion analysis using antibodies directed against distinct protein subunits of human RNase P, and the immunodepleted extracts were then assayed for transcription of human 5S rRNA, 7SL RNA, and U6 snRNA genes. Sharp declines in transcription of 5S rRNA, 7SL RNA, and U6 snRNA genes were evident in extracts immunodepleted with antibodies directed against the subunits Rpp20, Rpp21, and Rpp29 when compared with transcription in extracts treated with antibodies against the tumor suppressor gene p53 or preimmune serum (Fig. 3D-F, cf. lanes 1-3 and 5,6). As expected, extracts immunodepleted with anti-RPC32 antibody were deficient in transcription of these three small, noncoding RNA genes (Fig. 3D-F, lane 4).

The results described so far demonstrate that a multiprotein complex of human RNase $\mathrm{P}$ is required for effi- cient transcription of various small, noncoding RNA genes by Pol III.

\section{Reconstitution of Pol III transcription deficiency in extracts by exogenous RNase $P$}

To test that a proficient Pol III exists in RNase P-depleted extracts, we added a partially purified HeLa RNase $\mathrm{P}$, which was obtained from a DEAE anion-exchange chromatography column (see below; Jarrous and Altman 2001), and performed reconstitution of transcription of various small, noncoding RNA genes in RNase P-depleted extracts. Remarkably, the addition of a DEAE-purified RNase P (fraction F31; see below) restored the synthesis of 299-nt 7SL RNA transcript and 89-nt primary transcript of $\mathrm{tRNA}_{\mathrm{i}}{ }^{\mathrm{Met}}$ in whole HeLa extracts immunodepleted of RNase $\mathrm{P}$ activity with antibodies directed against Rpp21 or Rpp29 (Fig. 4A, cf. lanes 3,5 and 2,4). Similarly, the addition of immunoprecipi- 
Reiner et al.
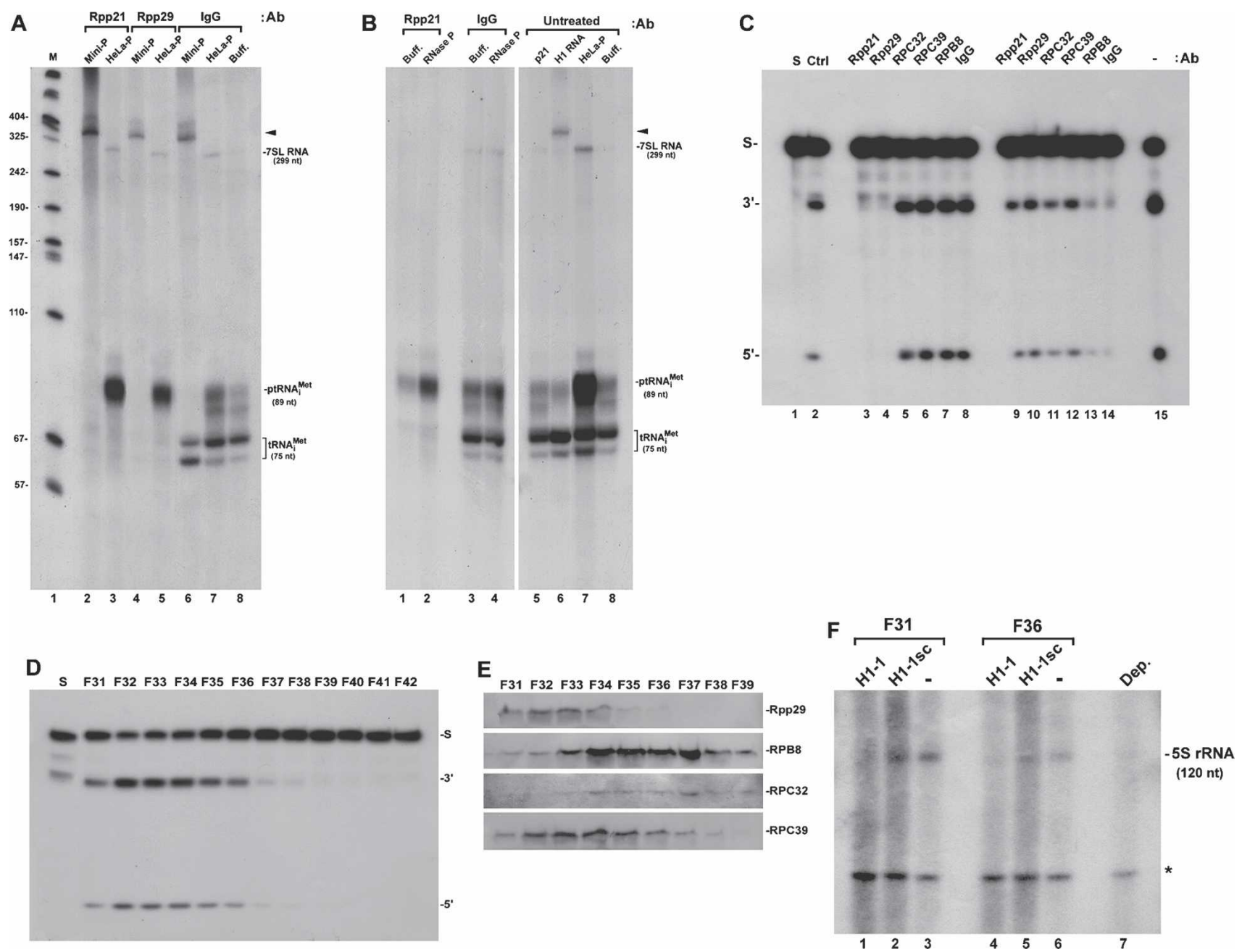

Figure 4. A purified RNase P can restore Pol III transcription deficiency. (A) Whole HeLa extracts were subjected to immunodepletion analysis using anti-Rpp21 (lanes 2,3), anti-Rpp29 (lanes 4,5), or anti-human IgG (lanes 6-8) antibodies. A DEAE-purified RNase P (HeLa-P; lanes 3,5,7; fraction F31) or mini-RNase P (Mini-P; lanes 2,4,6) was added to the immunodepleted extracts, and transcription of the 7SL RNA and tRNA ${ }_{i}^{\text {Met }}$ genes was performed as described in Figures 3E and 2E. Positions of 7SL RNA, precursor tRNA ${ }_{i}^{\text {Met }}$, and mature tRNA ${ }_{i}{ }^{M e t}$ are indicated. In lane 8, transcription buffer was added to IgG-treated extract. (Lanes 2,4,6) Arrowhead points to synthetic H1 RNA transcripts labeled with ${ }^{32}$ P-GTP by unknown enzymatic activity. $(B)$ Whole HeLa extracts were immunodepleted with anti-Rpp21 (lanes 1,2) or anti-human IgG (lanes 3,4) antibodies. Immunoprecipitates (lanes 2,4; RNase P) or transcription buffer (lanes 1,3; Buff.) were added back to the immunodepleted extracts, and transcription of the 7SL RNA and tRNA ${ }_{i}^{\text {Met }}$ genes was done as in Figure 3. Recombinant Rpp21 (lane 5), synthetic H1 RNA (lane 6), DEAE-purified RNase P (lane 7), or DEAE-column buffer (lane 8) (Jarrous and Altman, 2001) was added to untreated extracts, and transcription of the 7SL RNA and tRNA ${ }_{i}^{\text {Met }}$ genes was performed. (Lane 6) Arrowhead points to synthetic H1 RNA labeled in the extracts. (C) Immunodepleted extracts (lanes 3-8) and their corresponding immunoprecipitates (lanes 9-14) obtained with antibodies against Rpp21 (lanes 3,9), Rpp29 (lanes 4,10), RPC32 (lanes 5,11), RPC39 (lanes 6,12), RPB8 (lanes 7,13), or IgG (lanes 8,14) were assayed for RNase P activity; reaction time for enzyme activity in immunodepleted extracts (lanes 3-8) and the untreated extract (lane 15) was shorter than that of the immunoprecipitates (lanes 9-14). $(D)$ Fractions F31-F42 eluted from a DEAE anion exchange chromatography column (Jarrous and Altman, 2001) were tested for RNase $\mathrm{P}$ activity in processing of precursor tRNA ${ }^{\mathrm{Tyr}}$. (E) Fractions described in $D$ were tested for the presence of Rpp29, RPB8, RPC32, and RPC39 by Western blot analysis. (F) Transcription reactions of 5S rRNA gene in whole HeLa extracts depleted of RNase P activity by anti-Rpp21 antibodies (lane 7) but reconstituted with untreated DEAE fractions F31 (lane 3) and F36 (lane 6) described in D or with the same fractions after their treatment with RNase H and H1-1 (lanes 1,4) or scrambled H1-1sc deoxyoligonucleotide (lanes 2,5). Position of $5 \mathrm{~S}$ rRNA is shown. Asterisk points to a labeled tRNA ${ }^{\text {His }}$.

tated RNase $\mathrm{P}$ to its corresponding immunodepleted extract resumed transcription of these two genes (Fig. 4B, cf. lanes 1,2 and 3,4). However, the addition of a miniRNase P-which has only three components, Rpp21 and Rpp29, and H1 RNA (Mann et al. 2003)_failed to restore transcription (Fig. 4A, lanes 2,4), possibly because it lacks subunits found in the purified RNase P.

We noticed that the elution profile of active RNase P from the DEAE anion exchange chromatography column (Fig. 4D) described above partially overlapped with those 
of Pol III components; e.g., RPB8, RPC32, and RPC39 (Fig. 4E). Hence, we performed reconstitution assays of Pol III transcription in RNase P-depleted whole HeLa extracts using fractions F31 and F36 with comparable RNase P activity (Fig. 4D). Both fractions resumed 5S rRNA gene transcription in the immunodepleted extracts (Fig. 4F, cf. lanes 3,6 and 7), even though fraction F36 was enriched with RPB8, RPC32, or RPC39 when compared with fraction F31 (Fig. 4E). To provide direct evidence that RNase $\mathrm{P}$ is responsible for restoration of $5 \mathrm{~S}$ rRNA gene transcription, the H1 RNA moiety of RNase $\mathrm{P}$ in fractions F31 and F36 was targeted for cleavage by RNase $\mathrm{H}$ digestion using an antisense H1-1 deoxyoligonucleotide (see below). The treated fractions failed to restore $5 \mathrm{~S}$ rRNA gene transcription when compared with untreated ones (Fig. 4F, cf. lanes 1,4 and 3,6). Reconstitution of transcription was observed when fractions F31 and F36 were incubated with a scrambled H1-1 deoxyoligonucleotide, termed H1-1sc and RNase H (Fig. 4F, cf. lanes 2,5 and 7).

As noted above, whether reconstitution of Pol III transcription was done with endogenous RNase P or DEAEpurified RNase $\mathrm{P}$, newly transcribed 89 -nt primary transcripts of $\mathrm{tRNA}_{\mathrm{i}}{ }^{\text {Met }}$ were not processed to 75 -nt mature tRNA $_{i}{ }^{\text {Met }}$ (Fig. 4A [lanes 3,5], B [lane 2]). To verify that the DEAE-purified RNase $\mathrm{P}$ and the mini-RNase P used in the aforementioned reconstitution assays were functional in tRNA processing, we added them to IgG-treated (Fig. 4A, lanes 6,7) and untreated (Fig. 4B, lanes 5-8) whole HeLa extracts. In both cases, the DEAE-purified RNase P (fraction F31) enhanced transcription of the 7SL RNA and RRNA $_{i}{ }^{\text {Met }}$ genes and accelerated the maturation of tRNA ${ }_{i}^{\text {Met }}$ (Fig. 4A,B, cf. lanes 7 and 8). The miniRNase $P$ had no effect on transcription of these genes, but it did elicit formation of 75-nt tRNA $_{i}{ }^{\text {Met }}$ (Fig. 4A, cf. lanes 6 and 8), a finding that is in agreement with reconstitution experiments showing that the mini-RNase $\mathrm{P}$ has endonucleolytic activity in vitro (Mann et al. 2003).

Targeted cleavage of H1 RNA alters enzyme specificity of RNase $P$ and diminishes Pol III transcription

Several antisense deoxyoligonucleotides designed to anneal to the catalytic and specificity domains of H1 RNA (Fig. 5A), including the H1-1 deoxyoligonucleotide described above, were tested for targeted inactivation of RNase P in whole HeLa extracts by the use of RNase H (see Materials and Methods). Two of these deoxyoligonucleotides, H1-1 and H1-8 (Lee et al. 1996), were found to mediate cleavage of synthetic H1 RNA transcripts by RNase H (Fig. 5B, lanes 6,7). In whole HeLa extracts preincubated with RNase $\mathrm{H}$ and $\mathrm{H} 1-1$ deoxyoligonucleotide, transcription of the $5 \mathrm{~S}$ rRNA gene was reduced by up to $\sim 70 \%$ (Fig. 5C, lanes 4-6) when compared with transcription in the control extract incubated with the H1-1 deoxyoligonucleotide alone (Fig. 5C, lane 2). A reduction of $\sim 40 \%$ in gene transcription was measured in extracts incubated with H1-8 deoxyoligonucleotide and RNase H (Fig. 5C, cf. lanes 7-9 and 3). Treatment of extracts with RNase $\mathrm{H}$ and $\mathrm{H} 1-1$ but not scrambled $\mathrm{H} 1$ 1sc deoxyoligonucleotide caused severe reductions in transcription of several small, noncoding RNA genes, including 7SL RNA (Fig. 5E, cf. lanes 2 and 3), 5S rRNA (Fig. 5E, cf. lanes 4 and 5), tRNA ${ }^{\text {Tyr }}$ (Fig. 5E, cf. lanes 6 and 7), and tRNA ${ }_{i}{ }^{\text {Met }}$ (Fig. 5E, cf. lanes 8 and 9) genes. In the case of the 7SL RNA gene, a notable reduction of $-95 \%$ in its transcription was measured in extracts treated with $\mathrm{H} 1-1$ versus $\mathrm{H1}-1 \mathrm{sc}$ (Fig. 5E, cf. lanes 2 and 3). Since the H1-1, but not H-1sc, deoxyoligonucleotide is designed to anneal to H1 RNA, the former deoxyoligonucleotide can affect H1 RNA conformation and function. This can explain the large inhibitory effect of the H1-1 deoxyoligonucleotide on 5S rRNA gene transcription when it was compared with H1-1sc (Fig. 5E, cf. lanes 4 and 5) and not H1-1 (Fig. 5C, cf. lanes 6 and 2).

A defect in RNase $\mathrm{P}$ activity, as manifested by incorrect cleavage of the 5' leader sequence of the Schizosaccharomyces pombe precursor tRNA ${ }^{\text {Ser }}$ (pSupS1) was seen in extracts incubated with RNase $\mathrm{H}$ and $\mathrm{H} 1-1$ or H1-8 deoxyoligonucleotide (Fig. 5D, lanes 5-10; arrow). By contrast, extracts treated with $\mathrm{H} 1-1$ or H1-8 deoxyoligonucleotide without RNase $\mathrm{H}$ exhibited accurate cleavage of this substrate by RNase P (Fig. 5D, lanes 3,4). Similarly, miscleavage of the Escherichia coli precursor tRNA $^{\text {Tyr }}$ by RNase P was also evident in whole HeLa extracts treated with RNase $\mathrm{H}$ and H1-1 (Supplementary Fig. 1, lane 4) or H1-8 (Supplementary Fig. 1, lane 3) deoxyoligonucleotide.

Since the H1-1 and H1-8 deoxyoligonucleotides target the specificity domain of H1 RNA (Fig. 5A), which is implicated in substrate recognition by RNase P (Mann et al. 2003), the findings described above support the notion that properly active RNase $\mathrm{P}$ is required for transcription of small, noncoding RNA genes carrying the three basic types of Pol III promoters.

RNase $P$ is required for Pol III transcription in the cell

HeLa cells at $\sim 40 \%$ confluence were transiently transfected with siRNA38 (see Materials and Methods), a small interfering RNA (siRNA) shown to target the subunit Rpp38 of human RNase P (Cohen et al. 2003), and whole-cell extracts were prepared at various time points after transfection. An efficient knockdown of Rpp38 was measured in siRNA38-transfected cells when compared with control cells (Fig. 6A, cf. lanes 1-3 and 4-6), while expression of the subunit Rpp40 as well as $\beta$-actin was not affected (Fig. 6B,C). This targeted knockdown of Rpp38 was accompanied by a marked reduction in the activity of RNase P in tRNA processing (Fig. 6D). Strikingly, while the 5S rRNA gene was transcribed in extracts obtained from untransfected cells (Fig. 6E, lanes $5,6)$, no transcription was seen in extracts prepared from the siRNA38-treated cells (Fig. 6E, lanes 2,3). The lack of transcription in the control extract prepared from cells harvested at $66 \mathrm{~h}$ after transfection (Fig. 6E, lane 7) was 

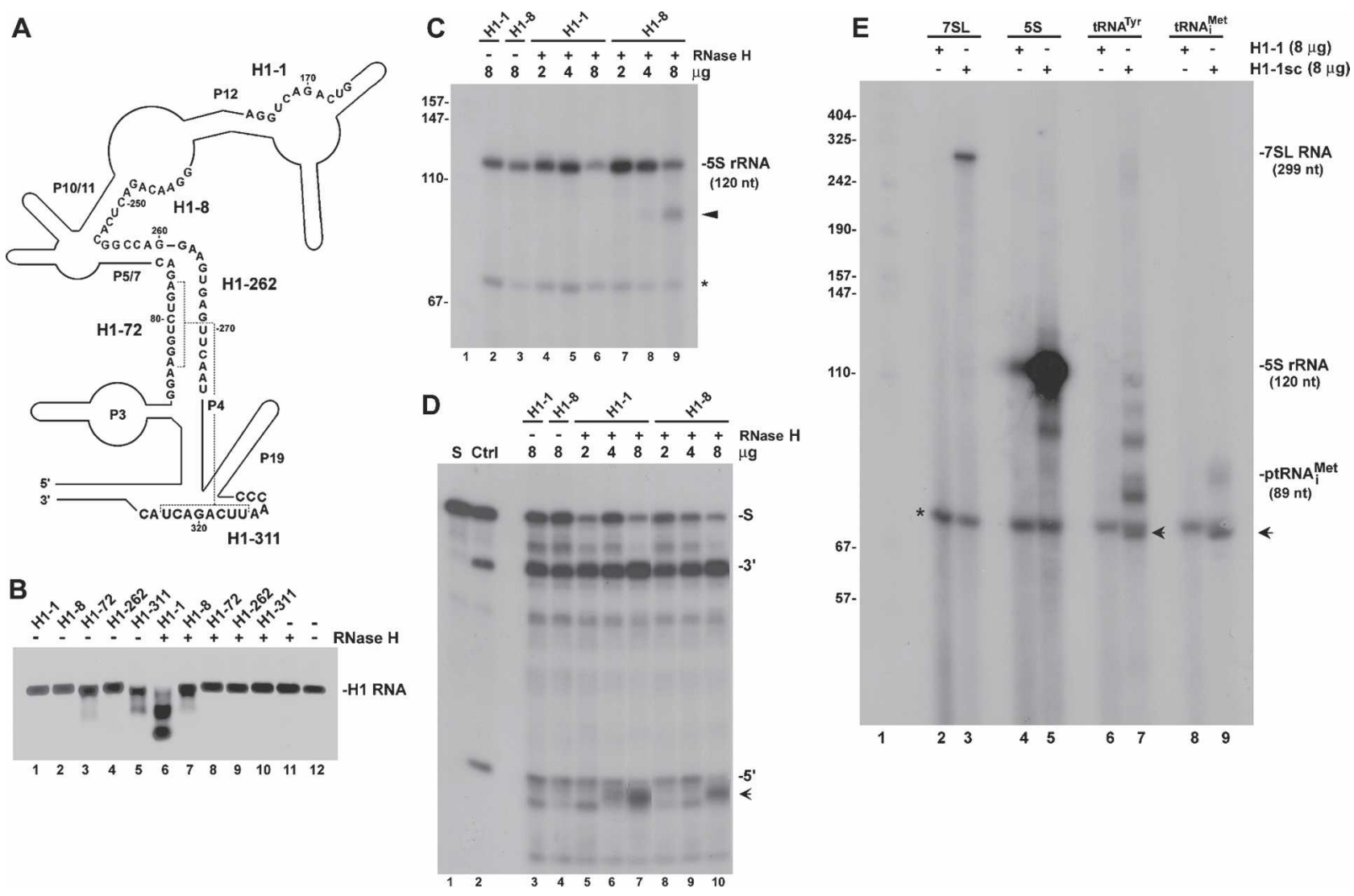

Figure 5. Targeted cleavage of H1 RNA diminishes Pol III transcription. (A) A predicted secondary structure of H1 RNA and the nucleotide sequences against which antisense H1-1, H1-8, H1-72, H1-262, and H1-311 deoxyoligonucleotides were directed. Conserved domains, including the P4 pseudoknot are shown. (B) In vitro transcribed H1 RNA (0.4 $\mu \mathrm{g})$ was incubated with $2 \mu \mathrm{g}$ of H1-1 (lanes 1,6), H1-8 (lanes 2,7), H1-72 (lanes 3,8), H1-262 (lanes 4,9), or H1-311 (lanes 5,10) deoxyoligonucleotide in the presence or absence of RNase H (15 U). As control, H1 RNA was incubated with RNase H (lane 11) or digestion buffer (lane 12) alone. Products of the cleavage reactions were separated in $1 \%$ agarose gel. $(C)$ Whole HeLa extracts $(10-15 \mathrm{mg} / \mathrm{mL}$ ) were incubated with 2, 4, and $8 \mu \mathrm{g}$ of H1-1 (lanes 4-6) or H1-8 (lanes 7-9) deoxyoligonucleotide in the presence of RNase H. As control, extracts were incubated with $8 \mu \mathrm{g}$ of H1-1 (lanes 2) or H1-8 (lane 3) deoxyoligonucleotide in the absence of RNase H. Transcription of 5S rRNA gene was performed as described in Figure 3D. Arrowhead points to premature or incorrectly cleaved $5 \mathrm{~S}$ rRNA. Asterisk points to labeled tRNA ${ }^{\text {His }}$. $(D)$ Extracts described in $C$ were assayed for RNase P activity in processing of $S$. pombe precursor tRNA ${ }^{\text {Ser }}$ (pSupS1), and cleavage products were analyzed in an $8 \%$ sequencing gel. (Lanes 7,10) The $5^{\prime}$ leader sequence and shorter species (arrow), which were generated as a result of substrate miscleavage, are indicated. (E) Extracts were incubated with RNase $\mathrm{H}$ in the presence of $8 \mu \mathrm{g}$ of $\mathrm{H1}-1$ (lanes 2,4,6,8) or H1-1sc (lanes 3,5,7,9) deoxyoligonucleotide, and then transcription of the 7SL RNA, 5S rRNA, tRNA ${ }^{\text {Tyr }}$, and tRNA ${ }_{i}^{\text {Met }}$ genes was performed as described in Figures 2 and 3. Arrows point to mature tRNA ${ }^{\text {Tyr }}$ and tRNA $_{i}{ }^{\text {Met }}$. Asterisk points to labeled tRNA ${ }^{\text {His }}$.

due to cessation of cell proliferation in the 3-d-old culture (see below).

To corroborate the role of RNase P in Pol III transcription, we targeted another subunit, Rpp29, for destruction by siRNA29 in transiently transfected HeLa cells. This siRNA, which was first described by others (Zhang and Altman 2004), knocked down Rpp29 by $95 \%$ when compared with its expression in cells transfected with a luciferase siRNA (Fig. 6F, cf. lanes 4-6 and 1-3). Whole extracts obtained from these siRNA29-transfected cells at 22,44 , and $66 \mathrm{~h}$ after transfection were defective in $5 \mathrm{~S}$ rRNA gene transcription (Fig. 6J, lanes 1-3). By contrast, whole extracts prepared from cells transfected with a luciferase siRNA showed active transcription of the $5 \mathrm{~S}$ rRNA gene (Fig. 6J, lanes 4-6).

To show that RNase $\mathrm{P}$ is required for Pol III promoter activity in living cells, HeLa cells were transfected with siRNA38 in the presence or absence of pU6-M1 RNA, in which a bacterial reporter gene encoding the M1 RNA subunit of E. coli RNase P (Guerrier-Takada et al. 1983) was abutted to a mouse U6 snRNA promoter (see Materials and Methods). Total RNA was extracted from cells, which were analyzed for RNase P activity (Fig. 7D, lanes 3-6), and expression of M1 RNA was determined by ribonuclease protection analysis (Fig. 7A) and Northern blot analysis (Fig. 7B) using an antisense, ${ }^{32}$ P-labeled M1 RNA as probe. While mock-transfected cells expressed high levels of full-length M1 RNA (377 nt in length) (Fig. 7A,B, lanes 4,5), expression of this transcript was reduced by $\sim 90 \%$ in siRNA38-treated cells (Fig. $7 \mathrm{~A}, \mathrm{~B}$ [lanes 2 and 3], C). By contrast, siRNA38 had no effect on expression of a green fluorescent protein gene fused 

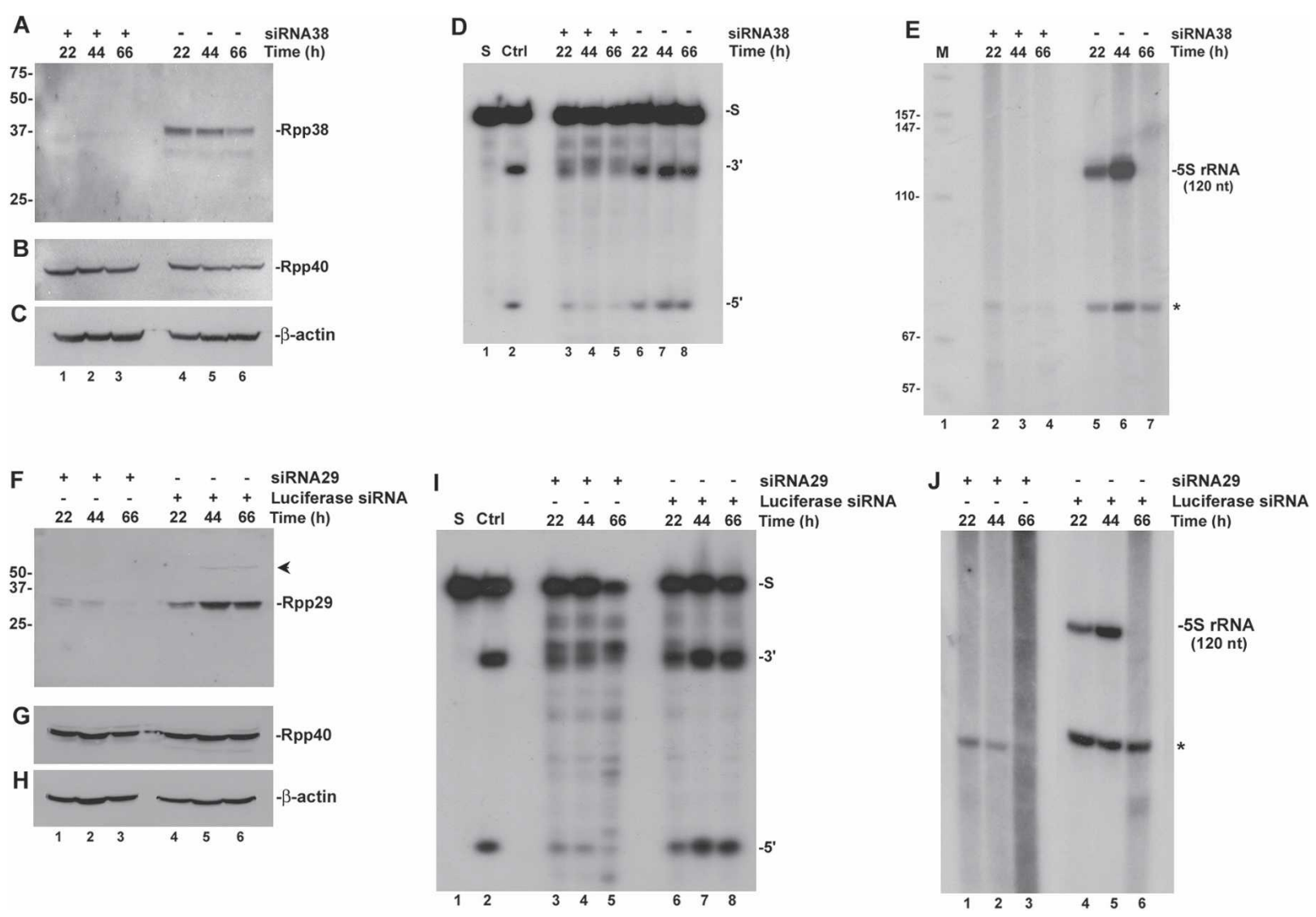

Figure 6. Inactivation of RNase P by RNAi results in inhibition of Pol III transcription in cells. $(A-C)$ HeLa cells were transfected with pBluescript in the presence or absence of siRNA38 (see Materials and Methods); whole extracts were then prepared from cells at 22, 44, and $66 \mathrm{~h}$ after transfection and examined by Western blot analysis for Rpp38, Rpp40, and $\beta$-actin. Positions of protein size markers are depicted. $(D)$ Extracts described in $A$ were assayed for endogenous RNase P activity. $(E)$ 5S rRNA gene transcription in extracts described in $A$. Position of the resultant 5S rRNA is shown, while asterisk represents labeled tRNA ${ }^{\text {His }}$. $(F-H)$ HeLa cells were transfected with siRNA29 (see Materials and Methods); whole extracts were prepared after 22, 24, and $66 \mathrm{~h}$ and tested for the presence of Rpp29, Rpp40, and $\beta$-actin as shown. Arrow points to a dimer form of Rpp29. $(I)$ RNase P assay of extracts described in $F$. (J). Transcription of $5 \mathrm{~S}$ rRNA gene in extracts shown in $F$.

to a Pol II promoter (e.g., CMV promoter) in cotransfected HeLa cells (data not shown). The different time courses for the effect of siRNA38 on the expression of M1 RNA in cells (Fig. 7A, lanes 2,3) versus 5S rRNA transcription in extracts (Fig. 6E, lanes 2,3 ) could be due to the time required for siRNA38 to work effectively in cotransfection procedures. Thus, the low expression of M1 RNA detected at $25 \mathrm{~h}$ (Fig. 7A, lane 2) could be due to the persistence of stable M1 RNA transcripts synthesized at earlier time after cotransfection of cells.

The findings described above reveal that inactivation of RNase P by RNA interference (RNAi) abolishes Pol III transcription and Pol III-directed promoter activity in the cell.

\section{A multiprotein RNase P complex associates with chromatin of tRNA and 5S rRNA genes}

Since RNase P is needed for Pol III transcription, we tested if it can associate with actively transcribed non- coding RNA genes by the use of chromatin immunoprecipitation (ChIP) analysis (see Materials and methods). Thus, ChIP assays were performed with HeLa cells using various antibodies directed against RNase P and Pol III subunits, and the immunoprecipitated chromatin materials were examined for enrichment of specific genes by PCR (see Materials and Methods). A PCR signal for a human tRNA $^{\text {Tyr }}$ gene was detected in chromatin samples precipitated by antibodies directed against Rpp14, Rpp21, Rpp30, and Rpp40 (Fig. 8A, lanes 1-4, respectively). This tRNA $^{\mathrm{Tyr}}$ gene was also enriched in chromatin preparations brought down by anti-RPB8 and anti-RPC32 antibodies (Fig. 8A, lanes 5 and 6) but not by preimmune rabbit serum or beads alone (Fig. 8A, lanes 7,8 ). PCR signals for tRNA ${ }^{\text {Leu }}$ and 5S rRNA genes were also detected in these chromatin preparations, except for the one obtained with the anti-Rpp30 antibody (Fig. 8A, lane 3; second and last panels), which could have failed to recognize its corresponding subunit in the chromatin context of these genes. The 7SL RNA gene was identified 
Reiner et al.
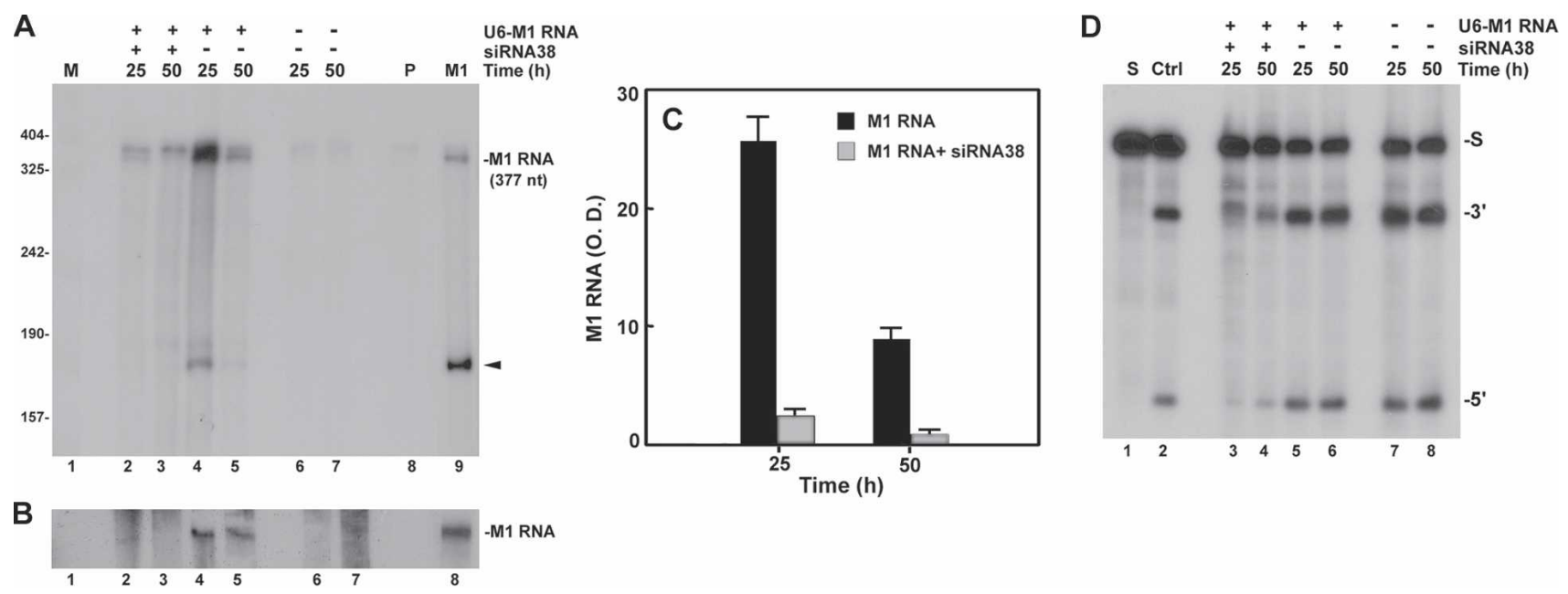

Figure 7. Inactivation of RNase P by RNAi causes inhibition of Pol III promoter activity in cells. $(A)$ HeLa cells were transfected with pU6-M1 RNA in the presence or absence of siRNA38. Total RNA was extracted from cells after 25 and $50 \mathrm{~h}$ of transfection and tested for expression of M1 RNA by ribonuclease protection analysis using antisense M1 RNA as probe. Position of the protected 377-nt M1 RNA is indicated. (Lane 9) As control, an in vitro transcribed 377-nt M1 RNA was analyzed (short exposure of the gel is attached); arrowhead points to a shorter, protected M1 RNA band. (Lane 8) Fully digested probe is shown. (B) Total RNA described in lanes 2-7 of $A$ was subjected to Northern blot analysis using a ${ }^{32}$ P-labeled M1 RNA as probe. (Lane 8) An in vitro transcribed 377-nt M1 RNA was also analyzed, and the position of the protected band is indicated. (C) Optical density (in arbitrary units) of the 377-nt M1 RNA bands seen in lanes 2-5 of $A$. $(D)$ Whole extracts prepared from HeLa cells described in $A$ were assayed for endogenous RNase P activity in processing of a labeled precursor tRNA ${ }^{\mathrm{Tyr}}$.

in chromatin samples precipitated by the anti-RPB8 antibody (Fig. 8A, lane 5).

The association of Rpp21 and Rpp29 with chromatin of tRNA ${ }^{\mathrm{Tyr}}$, tRNA ${ }^{\mathrm{Leu}}$, and 5S rRNA genes increased by fourfold to 10 -fold when HeLa cells grew from $30 \%$ to $60 \%$ confluence (Fig. 8B, cf. lanes 1,2 and 6,7 ) but then decreased when cells reached 95\% confluence (Fig. 8B, lanes 10,11), in which proliferation of the cells declined as determined by flow cytometry (data not shown). Rpp21 and Rpp29 did not bind to chromatin of the 7SL RNA and $\beta$-globin genes (Fig. 8B, lanes $1,2,6,7)$. The binding pattern of Rpp21 and Rpp29 to chromatin of the tRNA $^{\text {Tyr }}$, tRNA ${ }^{\text {Leu }}$, and $5 S$ rRNA genes resembled that of RPB8 (Fig. 8C-E), a core component of active Pol III. The increase in chromatin binding by these protein subunits of RNase P and Pol III in cells at $60 \%$ confluence (Fig. 8C-E) coincided with vigorous Pol III transcription seen in extracts obtained from cells with a comparable confluence (data not shown). However, Rpp29 disengaged from tRNA and 5S rRNA genes independently of Rpp21 and RPB8 in cells at 95\% confluence (Fig. 8B, cf. lanes 11 and 10,12). In addition, knockdown of Rpp29 in cells by the use of siRNA29 selectively eliminated the chromatin binding signal of Rpp29 but not that of RPB8 and Rpp21 to tRNA and 5S rRNA genes (Fig. 8F, cf. lanes 2 and 1,3). Rpp29 occupancy of these genes remained unchanged in cells transfected with a control, luciferase siRNA (Fig. 8F, lane 7). Thus, recruitment of Pol III (represented by RPB8) to tRNA and 5S rRNA genes, which occurs under conditions of inhibition of Pol III transcription in cells with knockdown of siRNA29 (Fig. 8G), does not require a functional RNase P.

\section{RNase P dissociates from chromatin of inactive $5 S$ $r R N A$ genes in mitotic cells}

To provide evidence that the association of RNase $\mathrm{P}$ subunits with chromatin of small, noncoding RNA genes is linked to active transcription, HeLa cells were synchronized to G2 and M phase by treatment with nocodazole, and then G2-enriched and mitotic cell populations (see Supplemental Material; White et al. 1995) were subjected to FACS analysis for determination of their DNA content (Supplementary Fig. 2A-C). Whole extracts were prepared from these two synchronized cell populations and tested for Pol III transcription (Supplementary Fig. 2D). Transcription of the 5S rRNA gene was inefficient in the mitotic extract when compared with transcription in the G2 extract (Supplementary Fig. 2D, cf. lanes 2 and 1), a finding that is consistent with a previous study (White et al. 1995). A decrease of $~ 50 \%$ in RNase P activity in processing of a precursor tRNA was also evident in the mitotic extract (Supplementary Fig. 2E, cf. lanes 3 and 4). ChIP analysis revealed that Rpp20 and Rpp29 were not bound to chromatin of the 5S rRNA genes in mitotic cells, when compared with cells at G2 phase (Supplementary Fig. 2G, cf. lanes 1,3 and 6,8). Rpp21 and RPB8 occupancy of 5S rRNA genes was also considerably reduced (Supplementary Fig. 2G, cf. lanes 2,4 and 7,9). This substantial decrease in chromatin binding by RPB8, which represents active Pol III, supports the weak in 

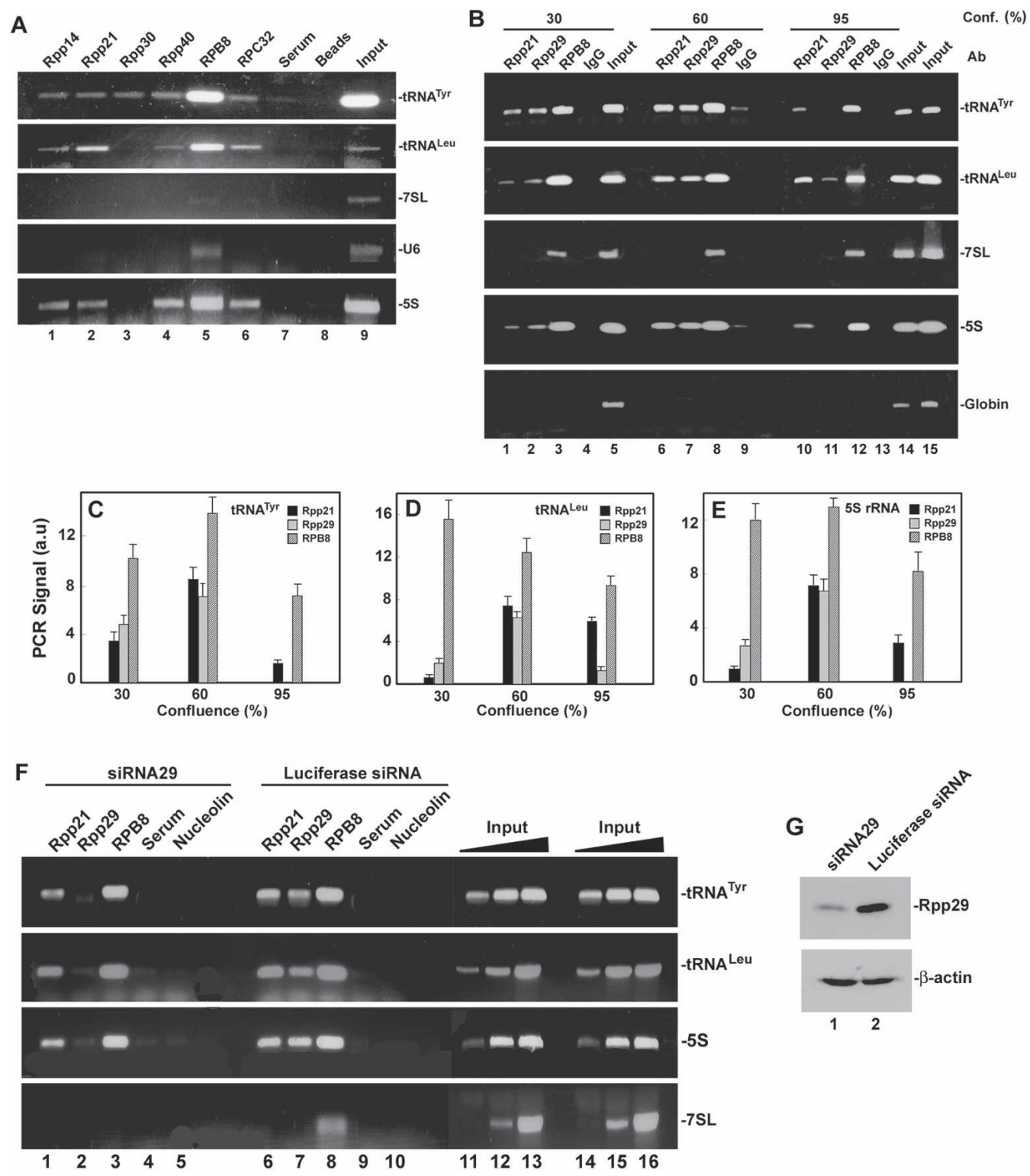

Figure 8. A multisubunit RNase P bound to chromatin of tRNA and 5S rRNA genes. (A) ChIP analysis (see Materials and Methods) was performed with HeLa cells grown to 30\% confluence using antibodies directed against Rpp14 (lane 1), Rpp21 (lane 2), Rpp30 (lane 3), Rpp40 (lane 4), RPB8 (lane 5), and RPC32 (lane 6) or preimmune serum (lane 7) or beads alone (lane 8). DNA extracted from the precipitated chromatin was analyzed by PCR for the presence of tRNA ${ }^{\text {Tyr }}$, tRNA ${ }^{\text {Leu }}$, 7SL RNA, U6 snRNA, and 5S rRNA genes. (Lane 9) Positive PCR reactions for each gene using $0.1 \%$ of extracted DNA are shown. (B) HeLa cells were grown for $30 \%$, $60 \%$, and $95 \%$ confluence and then subjected to ChIP analysis using antibodies directed against Rpp21 (lanes 1,6,10), Rpp29 (lanes 2,7,11), RPB8 (lanes $3,8,12$ ), and human IgG (lanes $4,9,13$ ). PCR amplification of tRNA $^{\text {Tyr }}$, tRNA ${ }^{\mathrm{Leu}}, 7 \mathrm{TL}$ RNA, 5S rRNA, and $\beta$-globin genes in the precipitated chromatin samples was done as described in $A$. Positive controls for PCR using $0.1 \%($ lanes 5,14$)$ and $0.4 \%($ lane 15$)$ of input DNA are shown. This panel is a composite of two agarose gels. $(C-E)$ Quantitation (in arbitrary units) of PCR bands seen in $B$ and that correspond to the tRNA ${ }^{\text {Tyr }}$, tRNA ${ }^{\text {Leu, }}$, and 5S rRNA genes brought down by antibodies directed against Rpp21, Rpp29, and RPB8. (F) HeLa cells at $40 \%$ confluence were transfected with siRNA29 or control luciferase siRNA for $42 \mathrm{~h}$ and then subjected to ChIP analysis using antibodies directed against Rpp21 (lanes 1,6), Rpp29 (lanes 2,7), RPB8 (lanes 3,8), preimmune serum (lanes 4,9), or nucleolin $\left(\mathrm{C} 23\right.$; lanes 5,10). PCR amplification of tRNA ${ }^{\text {Tyr }}$, tRNA ${ }^{\text {Leu }}$, and 5S rRNA and 7SL RNA genes was done as described in $B$. For linear PCR, $0.01 \%, 0.1 \%$, and $1 \%$ of input DNA from cells transfected with siRNA29 (lanes 11-13) or luciferase siRNA (lanes 14-16) were included. Each panel is a composite of two agarose gels. $(G)$ Whole extracts obtained from cells described in $F$ and that were transfected with siRNA29 or luciferase siRNA were examined for the presence of Rpp29 and $\beta$-actin by Western blot analysis.

vitro transcription capability of the mitotic extract (Supplementary Fig. 2D).

Taken together, the results described above reveal that a multiprotein complex of human RNase $\mathrm{P}$ is associated with chromatin of transcriptionally active small, noncoding RNA genes. In addition, this associa- 
tion is dynamic, in the sense that it is linked to the cell cycle.

\section{Discussion}

We have shown that human RNase P is required for normal and efficient Pol III transcription. Thus, depletion of active RNase $\mathrm{P}$ from whole HeLa extracts results in a severe deficiency in transcription of several small, noncoding RNA genes by Pol III. Human RNase P acts as an intact catalytic ribonucleoprotein in Pol III transcription since targeted cleavage of its H1 RNA moiety alters enzyme specificity and diminishes Pol III transcription. Furthermore, targeted inactivation of RNase P by RNAi eliminates Pol III function and reduces Pol III-directed promoter activity in the cell, thus providing a "reverse genetic" evidence for the vital role of RNase P in Pol III transcription. Our study unveils RNase $\mathrm{P}$ as a key factor in Pol III transcription and thereby implicates a primordial catalytic ribonucleoprotein in RNA polymerization.

A minimal system for human Pol III transcription has been described (Hu et al. 2003), whereby a purified Pol III complex and recombinant SNAPc, TBP, Brf2, and Bdp1 proteins can direct multiple rounds of transcription initiation and termination from a U6 snRNA promoter $(\mathrm{Hu}$ et al. 2003). However, some additional proteins, including $\beta$-actin, exist in the purified Pol III complex (Hu et al. 2004). Since some RNase P activity can be found associated with Pol III complexes in the cell, as shown in this work, further investigation is needed to clarify if the former particle is essential for basal Pol III transcription in vitro. Our immunodepletion experiments and targeted H1 RNA cleavage assays indicate that if a small amount of RNase P is left in whole HeLa extracts, this would be sufficient to support Pol III transcription, an observation that could also explain why RNase P has not been previously identified as a factor of human Pol III transcription.

A genetic screen in Saccharomyces cerevisiae identified the RPR1 gene, which codes for the RNA subunit of nuclear RNase $\mathrm{P}$, as a specific overexpression suppressor of very slow growth due to a short amino acid deletion in Bdp1, a component of TFIIIB (Ishiguro et al. 2002). This deletion in Bdpl specifically reduces transcription of the $R P R 1$ gene by affecting the TFIIIC-dependent assembly of TFIIIB on the RPR 1 promoter (Ishiguro and Kassavetis 2003). Bdp1 also interacts with RPR1 RNA, implying a potential role for TFIIIB in 5 '-end processing of precursor tRNA (Ishiguro and Kassavetis 2003). Combined with our work on the requirement of human RNase P for Pol III transcription, it seems that 5 '-end processing of tRNA is evolutionary linked to the transcription machinery from yeast to human. The correlation between transcription and processing of tRNA may not be restricted to 5 '-end processing. A recent study demonstrates that the subunit Rpc1lp of $S$. pombe Pol III, which has a role in transcription termination and $3^{\prime}$ tRNA cleavage, limits the length of 3 '-terminal oligo(U) tail in nascent precursor tRNAs and thus determines their subsequent processing through La-independent pathway (Huang et al. 2005).

\section{Mechanism of action of RNase P in Pol III transcription}

Protein subunits of human and yeast nuclear RNase P do not interact with components of the transcription machineries, as assessed by yeast two-hybrid genetic screens (Jiang and Altman 2001; see Xiao et al. 2002), though future studies that involve pull-down assays $\mathrm{Hu}$ et al. 2004) could help in revealing weak protein-protein interactions between RNase P and Pol III subunits. Nonetheless, the association of RNase P with Pol III in the cell could be facilitated by a third partner; e.g., tRNA gene. Our ChIP analyses uncover a multiprotein complex of RNase P that is associated with chromatin of transcriptionally active tRNA and 5S rRNA genes. RNase P subunits are maximally bound to chromatin of tRNA and 5S rRNA genes in dividing cells (Fig. 8) while dissociate from chromatin in mitotic cells (Supplementary Fig. 2). Hence, the association of RNase P and Pol III with chromatin of these target genes correlates with cell proliferation and cell cycle. Our results demonstrate that these two large molecular machines are associated in the context of chromatin, thus providing a mechanistic explanation of how RNase P exerts its role in Pol III transcription. However, knockdown of Rpp29 by RNAi does not eliminate binding of Pol III (represented by its core protein RPB8) to tRNA and 5S rRNA genes (Fig. 8F). In addition, Rpp29 dissociates from chromatin of these genes independently of RPB8 (Fig. 8B). Thus, Pol III occupancy of tRNA and 5S rRNA genes is not dependent on the presence of a functional RNase $\mathrm{P}$ in the cell. Whether Pol III or its transcription factors rather recruit RNase P on these target genes awaits thorough analysis.

In contrast to tRNA and 5S rRNA genes, the 7SL RNA and possibly U6 snRNA genes seem not to be bound by RNase P subunits as determined by ChIP analysis (Fig. 8). This latter finding suggests that RNase $\mathrm{P}$ has two modes of action in Pol III transcription. First, Pol III requires RNase P for general transcription, but the latter particle does not intimately bind to all genes. Second, RNase P binds to chromatin of genes that their nascent transcripts serve as its substrates; e.g., tRNA and probably 5S rRNA precursors.

\section{RNase P, Pol III, and transcription factories}

Coordination of the activities of several macromolecular machines involved in transcription, processing, and export of mRNA has been described (see Maniatis and Reed 2002; Proudfoot et al. 2002). These activities are coordinated in complex and extensive coupling networks that support the existence of "Pol II transcription factories" in the cell (see Cook 2002; Maniatis and Reed 2002). These networks become knotty as some of their components are also involved in tRNA processing (Paushkin et al. 2004). In S. cerevisiae, it has been shown that dispersed tRNA genes can cluster in a transcription-dependent manner in the nucleolus (Thompson et al. 2003), which could serve as a Pol III transcription factory. Similarly, biochemical and RNA cytochemistry experiments with human cells unveil the possible existence of Pol III 
transcription factories in the nucleoplasm (Pombo et al. 1999). Through mechanisms of chromatin mobility (Kosak and Groudine 2004; Osborne et al. 2004), tRNA genes from discrete genomic loci could be put close in nucleoplasmic or nucleolar regions enriched with macromolecular assemblies of transcription and processing machines, including Pol III and RNase P, for their coordinated expression at multiple levels.

\section{Materials and methods}

\section{Whole HeLa extracts, immunodepletion, and transcription}

HeLa cells were grown in 12-24 flasks of $175 \mathrm{~cm}^{2}$ and harvested at confluences specified in each experiment. Fifty percent confluence was obtained at $\sim 1 \times 10^{7}$ cells per flask. Adhered cells were detached by trypsin treatment followed by centrifugation. Whole HeLa extracts were then prepared as described by Baer et al. (1990). Protein concentrations in extracts were 10-15 mg/ $\mathrm{mL}$. For each immunodepletion assay, $25 \mu \mathrm{L}$ of extract diluted by $1: 1$ to $1: 2$ in dialysis buffer was incubated with an antibody coupled to Protein A/G agarose beads $(100-300 \mu \mathrm{L}$ serum with $40-50 \mu \mathrm{L}$ slurry beads). After $3 \mathrm{~h}$ of incubation at $4^{\circ} \mathrm{C}$, beads were centrifuged and supernatants were collected and assayed for RNase P activity and for Pol III transcription. The corresponding immunoprecipitates were washed three times with $1 \times$ NET2 buffer containing $150 \mathrm{mM} \mathrm{NaCl}$ and three times with $1 \times$ $\mathrm{PA}$ and assayed for RNase P activity.

In vitro transcription reactions of various noncoding RNA genes-e.g., the human tRNA $_{i}^{\text {Met }}$ (Drabkin and RajBhandary 1985), 7SL RNA (Kleinert et al. 1988), 5S rRNA (Sorensen and Frederiksen 1991), and U6 snRNA (Domitrovich and Kunkel 2003) genes-were performed in a final volume of $25 \mu \mathrm{L}$ that contained $15 \mu \mathrm{L}$ of extract, $1 \times$ transcription buffer $(12 \mathrm{mM}$ Tris$\mathrm{HCl}$ at $\mathrm{pH} 7.9,5 \mathrm{mM} \mathrm{MgCl}, 80 \mathrm{mM} \mathrm{KCl}, 0.5 \mathrm{mM} \mathrm{DTT}, 20 \mathrm{mM}$ creatine phosphate), NTPs $(0.5 \mathrm{mM}$ ATP, $0.5 \mathrm{mM}$ CTP, 0.05 mM GTP, $0.5 \mathrm{mM}$ UTP), $10 \mu \mathrm{Ci}$ of $\left[\alpha{ }^{-32} \mathrm{P}\right]-\mathrm{GTP}(3000 \mathrm{Ci} / \mathrm{mmol}$; Amersham), and 0.25-0.5 $\mu \mathrm{g}$ of plasmid DNA carrying the desired gene indicated in each experiment. After $1 \mathrm{~h}$ of incubation at $30^{\circ} \mathrm{C}$, reaction mixtures were diluted $1: 1$ with $\mathrm{H}_{2} \mathrm{O}$, passed through a G-50 column, diluted to $250 \mu \mathrm{L}$ with $1 \times$ digestion buffer $(20 \mathrm{mM}$ Tris- $\mathrm{HCl}$ at $\mathrm{pH} 7.9,250 \mathrm{mM}$ sodium acetate, 1 mM EDTA, $0.25 \%$ SDS), and digested with $120 \mu \mathrm{g} / \mathrm{mL}$ Proteinase $\mathrm{K}$ for $30 \mathrm{~min}$ at $37^{\circ} \mathrm{C}$. Reaction products were recovered following phenol:chloroform:isoamylalcohol extraction by ethanol precipitation. Labeled RNAs were analyzed in $8 \%$ polyacrylamide gels, and bands were visualized by autoradiography.

\section{RNase $H$ digestion assay}

Antisense deoxyoligonucleotides described in this article were first examined for targeting a synthetic H1 RNA transcript for destruction in RNase $\mathrm{H}$ digestion assays. Cleavage products of the H1 RNA were analyzed in agarose gels stained with ethidium bromide. For RNase $\mathrm{H}$ cleavage reactions of H1 RNA in the RNase P context, $15 \mu \mathrm{L}$ of whole HeLa extract (10-15 $\mathrm{mg} / \mathrm{mL}$; not diluted) was incubated with 1-8 $\mu$ g of each deoxyoligonucleotide (Sigma) and 1-15 U of E. coli RNase H (Takara Bio, Inc.) for $30-45 \mathrm{~min}$ at $30^{\circ} \mathrm{C}$ in a final volume of $25 \mu \mathrm{L}$. Cleavage reactions without $\mathrm{RNase} \mathrm{H}$ or with scrambled (the H1-1sc sequence was $5^{\prime}$-TTGCACAGCTC-3') or nonspecific deoxyoligonucleotides were performed in parallel. The effect of these treatments on RNase P activity in the extracts was determined by examining $5^{\prime}$-end processing of ${ }^{32} \mathrm{P}$-labeled $S$. pombe precursor tRNA ${ }^{\text {Ser }}$ or E. coli precursor tRNA ${ }^{\mathrm{Tyr}}$ and separation of the cleavage products in an $8 \%$ sequencing gel. An aliquot of $15 \mu \mathrm{L}$ from the treated extracts was then tested for in vitro transcription of various small, noncoding RNA genes as described above. When a DEAE-purified RNase P was targeted by RNase $\mathrm{H}, 0.1-1 \mu \mathrm{g}$ of deoxyoligonucleotides was tested instead.

\section{ChIP and PCR analysis}

ChIP analysis was done essentially as described by Gomez-Roman et al. (2003). Adherent HeLa cells were grown to various confluences, collected, washed with $1 \times$ PBS, and cross-linked with $0.5 \%$ NP-40/1× PBS containing $1 \%$ formaldehyde for 10 $\min$ at $37^{\circ} \mathrm{C}$. Cells were rinsed with ice-cold $0.5 \% \mathrm{NP}-40 / 1 \times$ PBS and incubated for $30 \mathrm{~min}$ in high-salt buffer $(1 \mathrm{M} \mathrm{NaCl}$ $0.5 \%$ NP-40, $1 \times$ PBS). Cells were collected, washed with $0.5 \%$ NP-40/1× PBS, and then resuspended in low-salt buffer $(0.1 \mathrm{M}$ $\mathrm{NaCl}, 0.1 \% \mathrm{NP}-40,10 \mathrm{mM}$ Tris- $\mathrm{HCl}$ at $\mathrm{pH}$ 8.0, 1 mM EDTA). After $30 \mathrm{~min}$, cells were centrifuged at $480 \times \mathrm{g}$ for $10 \mathrm{~min}$ and subjected to 10 strokes through a 23 -gauge needle. Nuclei obtained after centrifugation were resuspended in low-salt buffer containing $2 \%$ sarkosyl and transferred to a sucrose cushion $(0.1$ $\mathrm{M}$ sucrose, $0.1 \mathrm{M} \mathrm{NaCl}, 10 \mathrm{mM}$ Tris- $\mathrm{HCl}$ at $\mathrm{pH}$ 8.0, $1 \mathrm{mM}$ EDTA, $0.5 \%$ NP-40), and then spun for $10 \mathrm{~min}$ at $4000 \times \mathrm{g}$. The pellet was resuspended in TE $(10 \mathrm{mM}$ Tris- $\mathrm{HCl}$ at $\mathrm{pH} 8.0,1 \mathrm{mM}$ EDTA) and spun again, and genomic DNA was sheared by sonication $(14 \times 10 \mathrm{sec}$, duty cycle $30 \%)$ to produce stretches of chromatin of $400-1000$ base pairs $(\mathrm{bp})$ in length. The sonicated material was diluted in $1 / 10$ volume of $\times 11$ NET buffer $(1.65 \mathrm{M}$ $\mathrm{NaCl}, 550 \mathrm{mM}$ Tris- $\mathrm{HCl}$ at $\mathrm{pH} 7.4,5.5 \mathrm{mM}$ EDTA, 5.5\% NP-40).

The sonicated material $(\sim 1 \mathrm{~mL}$ volume $)$ was precleared for 30 min with $20 \mu \mathrm{L}$ of Protein A/G Plus agarose beads (Santa Cruz Biotechnology) first blocked with $2 \mu \mathrm{g}$ of salmon sperm (Invitrogen). After centrifugation, $0.1-\mathrm{mL}$ samples were subjected to IP overnight at $4^{\circ} \mathrm{C}$ using a nutating device with the appropriate antibody coupled to beads (coupling was for $6 \mathrm{~h}$ at $4^{\circ} \mathrm{C}$ ) and in the presence of $4 \mu \mathrm{g}$ of salmon sperm. Precipitated complexes were washed three times with $1 \mathrm{~mL}$ of RIPA buffer $(50 \mathrm{mM}$ Tris- $\mathrm{HCl}$ at $\mathrm{pH} 8.0,150 \mathrm{mM} \mathrm{NaCl}, 0.1 \%$ SDS, $0.5 \%$ deoxycholate, $1 \% \mathrm{NP}-40)$, three times with $1 \mathrm{~mL}$ of $\mathrm{LiCl}$ buffer $(10 \mathrm{mM}$ Tris- $\mathrm{HCl}$ at $\mathrm{pH}$ 8.0, $250 \mathrm{mM} \mathrm{LiCl}, 1 \mathrm{mM}$ EDTA $0.5 \%$ deoxycholate, $0.5 \% \mathrm{NP}-40$ ), and three times with $1 \mathrm{~mL}$ of TE. Immunoprecipitated material was eluted twice with $200 \mu \mathrm{L}$ of $1 \%$ SDS/TE and incubated overnight at $42^{\circ} \mathrm{C}$ in $0.4 \mathrm{~mL}$ volume of elution buffer containing $120 \mu \mathrm{g} / \mathrm{mL}$ Proteinase K. DNA was extracted twice with phenol/chloroform/isoamyl alcohol (25:24:1 v/v), ethanol-precipitated, washed with $70 \%$ ethanol, dried, and resuspended in $25 \mu \mathrm{L}$ distilled water for use in PCR analysis.

Each PCR reaction contained $3 \mu \mathrm{L}$ of primers (final concentration of $1 \mu \mathrm{M}$ ), $5 \mu \mathrm{L}$ of reaction mixture, and $4 \mu \mathrm{L}$ of DNA for each IP sample. Input DNA was diluted in distilled water before PCR. PCR amplification programs and primer sequences were described in Winter et al. (2000) and Gomez-Roman et al. (2003) (see Supplemental Material).

\section{Acknowledgments}

We thank Professor Peter Cook (Oxford University, UK) for kindly providing us with monoclonal antibodies directed against RPB6, RPB8, RPC32, and RPC39; Professors Hans J. Gross and Hildburg Beier (University of Wuerzburg, Germany) for a human RRNA $^{\mathrm{Tyr}}$ gene; Professor Uttam L. RajBhandary (MIT, MA) for a human initiator tRNA ${ }^{\text {Met }}$ gene; Professor Bernd-Joachim Benecke (Ruhr-University Bochum, Germany) 
for a human 7SL RNA gene; Professor Gary Kunkel (Texas A\&M University, TX) for a human U6 snRNA gene; and Professor Sune Frederiksen (University of Copenhagen, Denmark) for a human 5S rRNA gene. This research is supported by the Israel Science Foundation (grant \#549/01) and United StatesIsrael Binational Science Foundation (grant \#2001-017) to N.J.

\section{References}

Altman, S. 2000. The road to RNase P. Nat. Struct. Biol. 7: 827-828.

Baer, M., Nilsen, T.W., Costigan, C., and Altman, S. 1990. Structure and transcription of a human gene for H1 RNA, the RNA component of human RNase P. Nucleic Acids Res. 18: 97-103.

Clayton, D.A. 2001. A big development for a small RNA. Nature 410: 29-31.

Cohen, A., Reiner, R., and Jarrous, N. 2003. Alterations in the intracellular level of a protein subunit of human RNase $\mathrm{P}$ affect processing of tRNA precursors. Nucleic Acids Res. 31: 4836-4846.

Cook, P.R. 2002. Predicting three-dimensional genome structure from transcriptional activity. Nat. Genet. 32: 347-352.

Domitrovich, A.M. and Kunkel, G.R. 2003. Multiple, dispersed human U6 small nuclear RNA genes with varied transcriptional efficiencies. Nucleic Acids Res. 31: 2344-2352.

Drabkin, H.J. and RajBhandary, U.L. 1985. Site-specific mutagenesis on a human initiator methionine tRNA gene within a sequence conserved in all eukaryotic initiator tRNAs and studies of its effects on in vitro transcription. J. Biol. Chem. 260: 5580-5587.

Fairley, J.A., Kantidakis, T., Kenneth, N.S., Intine, R.V., Maraia, R.J., and White, R.J. 2005. Human La is found at RNA polymerase III-transcribed genes in vivo. Proc. Natl. Acad. Sci. 102: 18350-18355.

Gall, J.G. 2003. The centennial of the Cajal body. Nat. Rev. Mol. Cell Biol. 4: 975-980.

Geiduschek, E.P. and Kassavetis, G.A. 2001. The Pol III transcription apparatus. J. Mol. Biol. 310: 1-26.

Gomez-Roman, N., Grandori, C., Eisenman, R.N., and White, R.J. 2003. Direct activation of RNA polymerase III transcription by c-Myc. Nature 421: 290-294.

Guerrier-Takada, C., Gardiner, K., Marsh, T., Pace, N., and Altman, S. 1983. The RNA moiety of ribonuclease P is the catalytic subunit of the enzyme. Cell 35: 849-857.

Hopper, A.K. 1998. Nuclear functions charge ahead. Science 282: 2003-2004.

Hopper, A. and Phizicky, E.M. 2003. tRNA transfers to the limelight. Genes \& Dev. 17: 162-180.

Hu, P., Wu, S., and Hernandez, N. 2003. A minimal Pol III transcription system from human cells reveals positive and negative regulatory roles for CK2. Mol. Cell 12: 699-709.

. 2004. A role for $\beta$-actin in Pol III transcription. Genes \& Dev. 18: 3010-3015.

Huang, Y., Intine, R.V., Mozlin, A., Hasson, S., and Maraia, R.J. 2005. Mutations in the RNA polymerase III subunit Rpc1lp that decrease RNA 3' cleavage activity increase 3 '-terminal oligo(U) length and La-dependent tRNA processing. Mol. Cell. Biol. 25: 621-636.

Intine, R.V., Dundr, M., Misteli, T., and Maraia, R.J. 2002. Aberrant nuclear trafficking of La protein leads to disordered processing of associated precursor tRNAs. Mol. Cell 9: 11131123.

Ishiguro, A. and Kassavetis, G.A. 2003. A gene-specific effect of an internal deletion in the Bdp1 subunit of the RNA poly- merase III transcription initiation factor TFIIIB. FEBS Lett. 548: 33-36.

Ishiguro, A., Kassavetis, G.A., and Geiduschek, E.P. 2002. Essential roles of Bdp1, a subunit of Pol III initiation factor TFIIIB, in transcription and tRNA processing. Mol. Cell. Biol. 22: 3264-3275.

Jarrous, N. 2002. Human ribonuclease P: Subunits, function, and intranuclear localization. RNA 8: 1-7.

Jarrous, N. and Altman, S. 2001. Human ribonuclease P. Methods Enzymol. 342: 93-100.

Jarrous, N., Wolenski, J.S., Wesolowski, D., Lee, C., and Altman, S. 1999. Localization in the nucleolus and coiled bodies of protein subunits of the ribonucleoprotein ribonuclease P. J. Cell Biol. 146: 559-572.

Jiang, T. and Altman, S. 2001. Protein-protein interactions with subunits of human nuclear RNase P. Proc. Natl. Acad. Sci. 98: 920-925.

Jones, E., Kimura, H., Vigneron, M., Wang, Z., Roeder, R.G., and Cook, P.R. 2000. Isolation and characterization of monoclonal antibodies directed against subunits of human RNA polymerases I, II, and III. Exp. Cell Res. 254: 163-172.

Kleinert, H., Gladen, A., Geisler, M., and Benecke, B.J. 1988. Differential regulation of transcription of human 7 SK and 7 SL RNA genes. J. Biol. Chem. 263: 11511-11515.

Kosak, S.T. and Groudine, M. 2004. Gene order and dynamic domains. Science 306: 644-647.

Lamond, A.I. and Earnshaw, W.C. 1998. Structure and function in the nucleus. Science 280: 547-553.

Lee, B., Matera, A.G., Ward, D.C., and Craft, J. 1996. Association of RNase mitochondrial RNA processing enzyme with ribonuclease $\mathrm{P}$ in higher ordered structures in the nucleolus: A possible coordinate role in ribosome biogenesis. Proc. Natl. Acad. Sci. 93: 11471-11476.

Maniatis, T. and Reed, R. 2002. An extensive network of coupling among gene expression machines. Nature 416: 499-506.

Mann, H., Ben-Asouli, Y., Schein, A., Moussa, S., and Jarrous, N. 2003. Eukaryotic RNase P: Role of RNA and protein subunits of a primordial catalytic ribonucleoprotein in RNAbased catalysis. Mol. Cell 12: 925-935.

Osborne, C.S., Chakalova, L., Brown, K.E., Carter, D., Horton, A., Debrand, E., Goyenechea, B., Mitchell, J.A., Lopes, S., Reik, W., et al. 2004. Active genes dynamically colocalize to shared sites of ongoing transcription. Nat. Genet. 36: 10651071

Paushkin, S.V., Patel, M., Furia, B.S., Peltz, S.W., and Trotta, C.R. 2004. Identification of a human endonuclease complex reveals a link between tRNA splicing and pre-mRNA 3 ' end formation. Cell 117: 311-321.

Phizicky, E.M. 2005. Have tRNA, will travel. Proc. Natl. Acad. Sci. 102: 11127-11128.

Pombo, A., Jackson, D.A., Hollinshead, M., Wang, Z., Roeder, R.G., and Cook, P.R. 1999. Regional specialization in human nuclei: Visualization of discrete sites of transcription by Pol III. EMBO J. 18: 2241-2253.

Proudfoot, N.J., Furger, A., and Dye, M.J. 2002. Integrating mRNA processing with transcription. Cell 108: 501-512.

Roeder, R.G. 2003. The eukaryotic transcriptional machinery: Complexities and mechanisms unforeseen. Nat. Med. 9: 1239-1244.

Schramm, L. and Hernandez, N. 2002. Recruitment of Pol III to its target promoters. Genes \& Dev. 16: 2593-2620.

Sorensen, P.D. and Frederiksen, S. 1991. Characterization of human 5S rRNA genes. Nucleic Acids Res. 19: 4147-4151.

Thompson, M., Haeusler, R.A., Good, P.D., and Engelke, D.R. 2003. Nucleolar clustering of dispersed tRNA genes. Science 302: 1399-1401. 
van Eenennaam, H., Lugtenberg, D., Vogelzangs, J.H., van Venrooij, W.J., and Pruijn, G.J. 2001. hPop5, a protein subunit of the human RNase MRP and RNase P endoribonucleases. J. Biol. Chem. 276: 31635-31641.

van Tol, H., Stange, N., Gross, H.J., and Beier, H. 1987. A human and a plant intron-containing tRNA ${ }^{\mathrm{Tyr}}$ gene are both transcribed in a HeLa cell extract but spliced along different pathways. EMBO I. 6: 35-41.

Wang, Z. and Roeder, R.G. 1997. Three human Pol III-specific subunits form a subcomplex with a selective function in specific transcription initiation. Genes \& Dev. 11: 1315-1326.

White, R.J. 2005. RNA polymerases I and III, growth control and cancer. Nat. Rev. Mol. Cell Biol. 6: 69-78.

White, R.J., Gottlieb, T.M., Downes, C.S., and Jackson, S.P. 1995. Cell cycle regulation of RNA polymerase III transcription. Mol. Cell. Biol. 15: 6653-6662.

Winter, A.G., Sourvinos, G., Allison, S.J., Tosh, K., Scott, P.H., Spandidos, D.A., and White, R.J. 2000. RNA polymerase III transcription factor TFIIIC2 is overexpressed in ovarian tumors. Proc. Natl. Acad. Sci. 97: 12619-12624.

Wolin, S.L. and Matera, A.G. 1999. The trials and travels of tRNA. Genes \& Dev. 13: 1-10.

Woychik, N.A., Liao, S.M., Kolodziej, P.A., and Young, R.A. 1990. Subunits shared by eukaryotic nuclear RNA polymerases. Genes \& Dev. 4: 313-323.

Xiao, S., Scott, F., Fierke, C.A., and Engelke, D.R. 2002. Eukaryotic ribonuclease P: A plurality of ribonucleoprotein enzymes. Annu. Rev. Biochem. 71: 165-189.

Zhang, H. and Altman, S. 2004. Inhibition of the expression of the human RNase P protein subunits Rpp21, Rpp25, Rpp29 by external guide sequences (EGSs) and siRNA. J. Mol. Biol. 342: $1077-1083$. 


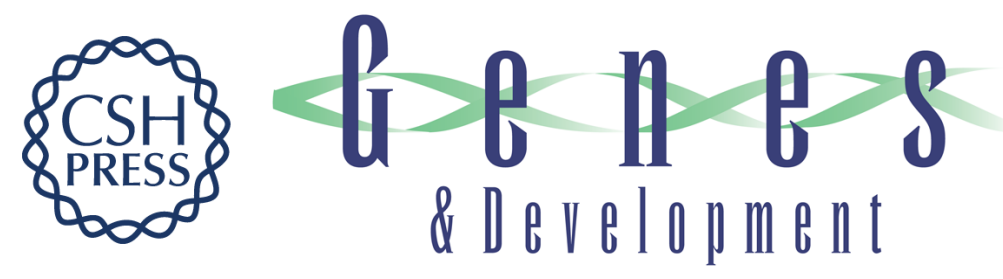

\section{A role for the catalytic ribonucleoprotein RNase $P$ in RNA polymerase III transcription}

Robert Reiner, Yitzhak Ben-Asouli, llana Krilovetzky, et al.

Genes Dev. 2006, 20:

Access the most recent version at doi:10.1101/gad.386706

\section{Supplemental http://genesdev.cshlp.org/content/suppl/2006/06/01/20.12.1621.DC1 Material}

References This article cites 50 articles, 23 of which can be accessed free at: http://genesdev.cshlp.org/content/20/12/1621.full.html\#ref-list-1

\section{License}

Email Alerting

Receive free email alerts when new articles cite this article - sign up in the box at the top Service 